\title{
Intertextuality and Stylization in Villa-Lobos's Bachianas Brasileiras № 1
}

\author{
Intertextualidade e Estilização \\ nas Bachianas Brasileiras № 1 de Villa-Lobos
}

\author{
Norton Dudeque \\ Universidade Federal do Paraná \\ norton.dudeque@ufpr.br
}

\begin{abstract}
In this text, intertextuality and stylization are discussed in the context of Villa-Lobos's Bachianas Brasileiras № 1. The cycle of Bachianas represents an homage to J. S. Bach, a stylization of Brazilian popular and folkloric music and Neoclassic elements. From a description of the w ork by the composer, three main matters are discussed: $a$. Tonality: classic harmonic atmosphere; $b$. Spiritualizing Bach's processes - Topics and learned style: chorale; Fugue d'école; polyphonic melody; and c. Typical Brazilian mood, as shown in the subtitle of each movement, Embolada, Modinha, and Conversa. Issues related to Neoclassicism are discussed according to Hyde's perspective of anachronistic imitations. In this sense, Villa-Lobos cycle of Bachianas represent a reverentialecletic type of Neoclassic work. Finally, intertextuality in general is addressed in relation to stylization, to Villa-Lobos theoretical background, and to the autonomy of the w ork.
\end{abstract}

Keywords: Villa-Lobos; intertextuality; stylization; Bachianas Brasileiras

Resumo: Neste texto discutimos as questões da intertextualidade e da estilização no contexto das Bachianas Brasileiras № 1 de Villa-Lobos. O ciclo das Bachianas representa uma homenagem a J. S. Bach, uma estilização da música popular e folclórica brasileira eelementos neoclássicos. A partir da descrição da obra pelo compositor, três questões principais são discutidas: a. Tonalidade: atmosfera harmônica clássica; b. Espiritualização dos processos de Bach - Tópicos e estilo culto: coral; Fugue d'école; melodia polifônica e c: Expressões brasileiras típicas, como indicado nos subtítulos de cada movimento, Embolada, Modinha e Conversa. Problemas relacionados com o neoclassicismo são discutidos sob a perspectiva de Hyde sobre imitações anacrônicas. Neste sentido, o ciclo das Bachianas de Villa-Lobos representa um tipo eclético e reverencial de obra neoclássica. Finalmente, abordamos a intertextualidade em geral em relação à estilização, aos fundamentos teóricos de Villa-Lobos e à autonomia da obra.

Palavras-chave: Villa-Lobos; intertextualidade; estilização; Bachianas Brasileiras 


\section{1 - Introduction}

Intertextuality in music has been explored in a number of publications dating from the 1990s which address the canonical repertoire and, more specifically, early twentieth-century music. One of the goals of these texts is to investigate how the music from the past may have influenced later music. In particular how composers of early twentieth century reinterpreted music material from earlier periods in their compositions. This material range from musical forms, tonality, chords, motives among other elements. The resulting music presents as characteristics, allusions, references, quotations, stylizations in a variety of ways, and particular to each composer, that produce a sort of style characteristic of neoclassicism in music. The aim of this text is to explore how Villa-Lobos adopts and reinterprets stylistic elements of the music of the past and of Brazilian popular music in the Bachianas Brasileiras № 1. As stylistic elements Villa-Lobos uses traditional tonality, allusions to the musical language of J. S. Bach, all mixed to nationalistic musical elements represented by Brazilian popular music.

Joseph Straus has summarized and concluded in Remaking the Past that

allusions to traditional tonal music permeate the music of this [twentieth] century. Some are overt, in the form of direct quotations or references, while others are concealed beneath the surface. They penetrate all levels of structure. Their treatment ranges from delicate changes of orchestration and transformation of single sonorities to the reinterpretation of entire forms and piece spanning motions. They are too numerous, too pervasive, too characteristic of twentieth-century music to be explained as anomalies. They cannot be ignored. They demand systematic explanation (Straus 1990, p. 184-185).

Straus continues observing that twentieth-century composers transform musical material from the past and adapt for their own needs. In this way, they reinterpret the music of the past ${ }^{1}$.

In another viewpoint, Korsyn (1991) argues that the intertextual approach to music analysis integrates different disciplines to music analysis. In fact, when considering matters of influence, biographical and theoretical background, different disciplines contribute to the intertextual aspects of the work being analyzed. Thus, historical musicology, history of music criticism and theory, play an important role in the "integrated intertextual approach" dispensed to a musical work. Consequently, the musical work turns to be considered as related to other musical works in a network of cultural/social associations that contribute to the evaluation of a specific music work. Korsyn summarizes that this approach

\footnotetext{
1 Straus writes: "by transmuting received materials, composers can push their precursors aside and clear creative space for themselves. In doing so, they remake the past" (1990, p. 185).
} 


\begin{abstract}
integrates musicology, theory and criticism, giving us a method of critical evaluation that is both historical and analytical; it accommodates the paradoxes of influence, showing originality and tradition, continuity and change in dialectical relation. Even if one rejects the idea of an organic work (as deconstruction advocates), it provides a model for analyzing compositions as relational events rather than as closed and static entities (Korsyn 1991, p. 61).
\end{abstract}

These two perspectives delineate the analytical approach in this text, they contribute on how to address intertextual relationships in Villa-Lobos's Bachianas Brasileiras № 1. In the text that follows, intertextuality is addressed from a viewpoint which maps elements of stylistic allusion, adoption and adaptation of compositional procedures that refer to J. S. Bach's music, Villa-Lobos's theoretical background, the stylistic features of Villa-Lobos's music, and to Brazilian popular music.

Afonso Romano de Sant'Anna (2003) proposes an approach to intertextuality that emphasizes, in three models, the relationship between parody, paraphrases, stylization and appropriation. The two poles are parody, which represents the inversion of the original meaning of the precursor text, and paraphrases, which represents the same meaning as the original text by presenting a similar idea, however rewritten. To mediate between these two poles, the author considers stylization, applied in more or less degree, as a defining factor. The graph contained in Figure 1, which is adapted from the models proposed by Sant'Anna (2003), summarizes this idea:

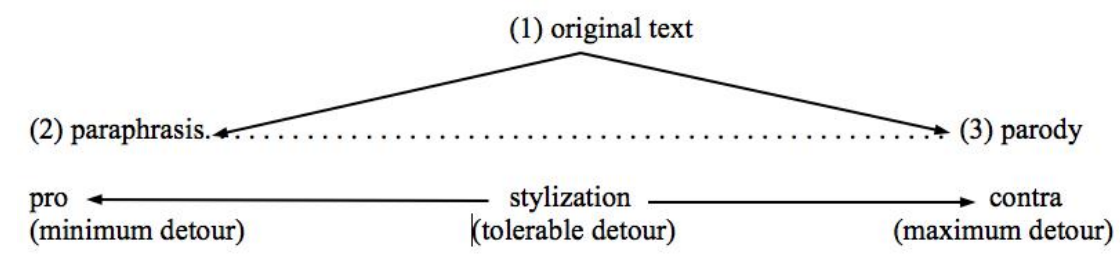

Figure 1: MODEL (adapted from Sant'Anna, 2003, p. 36)

Despite many attempts, as observed by Nogueira (2003), there still is a lack of systematization of intertextual categories applicable to a wide repertory of western art music. She proposes criteria for the classification of intertextual styles based on the re-contextualization of appropriated texts. The first refers to music parameters, such as: rhythm, melody, texture, harmony, etc. The second refers to how close the intertext is to the original text. Here, Sant'Anna's model can elucidate how intertextual relationships may be measured in a more or less degree of proximity to its earlier texts. In this sense, Straus (1990) observes that composers of the twentieth century shared musical techniques in order to rework 
earlier forms and stylistic elements, e.g., harmony, melody, texture, etc. He coins the following musical revisionary ratios $^{2}$ and suggests that they are strategies adopted by twentieth-century composers and that they may define "a twentiethcentury common practice" (p. 17). Among these are:

Motivicization. The motivic content of the earlier w ork is radically intensified.

Generalization. A motive from the earlier work is generalized into the unordered pitch-class set of which it is a member [...].

Marginalization. Musical elements that are central to the structure of the earlier work $[\ldots]$ are relegated to the periphery of the new one.

Centralization. Musical elements that are peripheral to the structure of the earlier w ork $[\ldots]$ move to the structural center of the new one.

Compression. Elements that occur diachronically in the earlier work are compressed into something synchronous in the new one.

Fragmentation. Elements that occur together in the earlier work $[\ldots]$ are separated in the new one.

Neutralization. Traditional musical elements [...] are stripped of their customary function $[\ldots]$.

Symmetrization. Traditionally goal-oriented harmonic progressions and musical forms [...] are made inversionally or retrograde-symmetrical, and are thus immobilized (Straus 1990, p. 17).

These techniques are tools for composers to produce relationships in their own compositions with the music of the past. If on one hand, as Straus puts it, these techniques may contribute to the expression of musical neoclassicism, that is, musical works that embrace a simple, objective and balanced structure, on the other hand, they also contribute to produce a progressive type of work, which presents complex, asymmetrical and developmental structures (p. 1-2), opposed to neoclassical structures. Therefore, the techniques represent a broad set of compositional procedures that can be analytically identified in musical works of the first half of the twentieth century.

Making references to works of composers of the past as a compositional strategy to develop musical ideas are frequent in early twentieth-century music. Perhaps, the most explored examples of this strategy can be found in Stravinsky's neoclassical works and in Schoenberg's use of traditional musical forms. VillaLobos is no exception, he also explored references to the music of the past as a source of inspiration in the development of musical ideas.

Despite the vast literature on the reception of J. S. Bach's works, there is still the need, in some cases, to observe how composers react to re-readings of Bach's music, how they stylize their own music as to, either, pay homage to Bach or to be inspired by Bach's music. Finscher (1998), for instance, observes two distinct ways of speaking about Bach in the nineteenth century: the first,

\footnotetext{
2 Based on Bloom's revisionary ratios, for a synopsis see Bloom (1997), p. 14-16.
} 
"creating an altogether mythological, cosmological, superhuman Bach"; the second, "speaking soberly in terms of musical craft", i.e., to speak of Bach's musical composition techniques rationally and consciously (p. 6). In the case of Villa-Lobos's Bachianas Brasileiras, one of the main concerns with stylization is the association to neoclassicism. However, his neoclassic music is categorized by a more inclusive approach that includes nationalistic elements, with allusions or citations to popular Brazilian music, than the one which emphasizes characteristics of simplicity, youth, objectivity and cultural elitism as pointed by Messing (1988, p. 89)3 . In her discussion on neoclassicism, Hyde (1996) identifies two general modes of allusions to the classics, antiquarianism and accommodation. For the latter, she identifies two types: allegory, and metamorphic anachronism, which presents any confrontation between periodstyles, for example, classic in the twentieth-century music. In order to categorize, Hyde proposes four types of imitations: reverential, eclectic, heuristic, and dialectical. The most pertinent to Villa-Lobos's Bachianas refers to a mixed type of reverential and eclectic imitation. Hyde summarizes the main characteristics of reverential imitation, which is as a simple strategy that 'follows the classical model with a nearly religious fidelity or fastidiousness' (p. 206). She compares and analyses Couperin's Forlane from Concerts royaux, Quatrieme concert, and Ravel's Forlane from Le tombeau de Couperin. She sums up:

the imitation celebrates the classical model by almost ritual repetition [...] But this kind of reverent reproduction of a model has difficulty, I think, functioning transitively, for the reproduction must be made in an idiom that is alien or unbecoming to the original and whose violations of the model's norms threaten to remain out of artistic control (Hyde 1996, p. 210).

For eclectic imitations, Hyde argues that they present allusions, phrases, techniques, forms and structures borrowed from the music of earlier composers and styles, assembled together indistinctly. She observes these characteristics mainly in the Stravinsky's neoclassic music:

Such an eclectic mingling features prominently in the early neoclassic w orks of Stravinsky, which often join both diatonic and octatonic pitch structures and selfconsciously imitate classical phrase structure, simple dance patterns, various tonal forms, and Baroque contrapuntal textures. We can call this type of imitation eclectic or exploitative. [...] Eclectic imitation describes a process by which sources and models are compiled. Rather than a well-organized museum, tradition becomes a w arehouse whose contents can be rearranged and plundered without damage or responsibility (Hyde 1996, p. 211).

\footnotetext{
3 1. Simplicity - the reaction against obscurity, density, and size; 2. Youth - the belief that spontaneity, freshness, and vigor could often be best characterized by evoking the childlike condition; 3. Objectivity - the response to the notion that intensely personal utterances led to either distortion and rank sentimentality; 4 . Cultural elitism - the posture that the previous elements were all inherent in non-Germanic peoples. See Messing (1988), p. 89.
} 
Both types of imitations are appropriate for the evaluation of the Bachianas Brasileiras which represents a reverential homage to J. S. Bach, with references to Brazilian popular music, allusions to classic harmonic atmosphere, stylistic imitation of Bachian compositional techniques, and even to Villa-Lobos known theoretical background. They characterize a "cauldron" of diverse music material assembled in a variety of ways producing a distinct music, but always recognizable as Villa-Lobos's Bachianas and as an homage to J. S. Bach.

One of the noticeable analytic problems caused by this sort of eclectic imitation in musical works, is what Toorn (1997) observes in relation to Stravinsky's neoclassic works, i.e. the metaphor of the organic unity (or wholeness) is more difficult to prove due to the anachronistic juxtaposed elements. In neoclassicism, the old stylistic references are regenerated into the new style, or as Toorn puts it, "the new is defined to some extent by the old, by an awareness of what it is that is being transformed" (p. 133). Furthermore, the difficulty lies in the apparent lack of a unified design or synthesis in the components of neoclassical works, and this reflects directly in the kind of possible analysis to demonstrate the integration of old and new in neoclassic musical works. In the analysis that follows, I adopted "Schenkerian inspired structural analysis" ${ }^{\prime 4}$ despite the problematic application of traditional methods of analysis, such as the Schenkerian model, which is concerned with the organic unity of a musical work. The eclectic imitation, according to Hyde, may be seen more as a process in which old and new components are mixed to construct the musical discourse. References to Bach's music, traditional tonality, Brazilian popular music, Villa-Lobos's own stylistic peculiarities, all are mixed in the Bachianas raising difficulties to identify these elements and to analyze its own consistency. Moreover, surface components of the music may be worthwhile to identify since they may contribute to compose the intertextual relations to other works, and styles. In fact, foreground to middleground level components may constitute recurring compositional elements that can characterize a specific topic in the work. For instance, Villa-Lobos frequently alludes to chorale settings which has a specific texture, harmonic progressions and voice leading structure ${ }^{5}$, as will be discussed below.

\footnotetext{
${ }^{4}$ I intend that the Schenkerian inspired analytical examples show aspects of the structure of the w ork analysed. The examples must not be considered according to a traditional Schenkerian analysis.

${ }^{5}$ Contrary to this observation, Wright argues that is not necessary an identification of Bachian elements in the Bachianas since they are self-evident and consist mostly of foreground idiomatic figures. He writes: 'It w ould be futile to enumerate, as some have, all the Bachian techniques and turns of phrase employed in the series. They are self-evident and occur in the main as superficial adornment to w orks which have little or no real connection with Bach at all'. See Wright (1992), p. 85.
} 
Finally, Tarasti (1995) offers six "codes" to which the Bachianas should be considered: 1) the code of baroque music; 2) the code of Brazilian folk music; 3) the code of musical form; 4) the sonorous code; 5) the referential code [...] in the history of twentieth-century art music; 6) the aesthetic code [...] or the aesthetic value of these works (p. 85). Each of these codes approaches a specific question for the Bachianas. The first four addresses the "adaptation" of the stylistic features of Bach's music, Brazilian folk music, traditional forms and tonality, timbre (or orchestration), and the extent to which Villa-Lobos goes into these references. The remaining two codes address the more general issues in regards to value judgements of the Bachianas cycle.

\section{2 - Context}

The cycle of nine Bachianas Brasileiras represents a sophisticated conception of neoclassic works. Villa-Lobos aims for a mixture of an homage to Bach, by applying his perception of Bach's compositional techniques, and nationalistic references to Brazilian music. Composing the cycle of Bachianas Brasileiras during the period of 1930 to 1945, Villa-Lobos adopted a tendency towards neoclassicism and the neobaroque established in Europe during the 1920s. Consequently, he adopted references to Bachian music style and demonstrated a great interest in Bach's music during the 1930s and 40s. At the time Villa-Lobos composed his series of Bachianas Brasileiras, he was involved in several projects related to the music of J. S. Bach. For instance, in 1938, he arranged the Organ Fantasia and Fugue No. 6 for orchestra, and between 1932 and 1937, he arranged Preludes and Fugues from the Well-Tempered Clavier for mixed choir ${ }^{6}$. Most of these arrangements were written for choir performances in a music education program (Canto Orfeônico), in which Villa-Lobos was the leading figure.

In a somewhat curious description of his perception of the universality of Bach's music, Villa-Lobos wrote in 1947 an explanation about the Bachianas Brasileiras:

${ }^{6}$ (WTC) №s 4 (1934), 8 (1932), 14 (1937), 22 (1932) and Fugues 1 (1932), 5 (1932), 8 (1932), 21 all arranged in 1932. Villa-Lobos's interest in counterpoint and fugal procedures seems to go far beyond Bach's music. For instance, in the collection Solfejos, Vol. 2, published in 1946, Villa-Lobos composed for the collection several 2, 3, 4 and 6 parts canons, arranged circular 4 part scanons by Francisco Braga (1868-1945), a twelve-tone Fugue by Max Brand (1896-1980), a 4 parts Fugue by Handel and the 4 parts Fugue No. 8 from WTC by J. S. Bach. But more interesting is Villa-Lobos own Fugue entitled Fuga IV sobre um tema de caráter popular brasileiro for mixed choir, an arrangement of the orchestral Fugue - the fourth movement - in Bachianas Brasileiras № 8 (1944). See Villa-Lobos (1946). 
Bachianas Brasileiras - title of a type of musical composition created from 1930 to 1945 to pay homage to the great genius of Johann Sebastian Bach. The Bachianas Brasileiras, numbering nine suites, are inspired on the musical atmosphere of Bach, considered by its composer as a universal folkloric source, rich and profound, with all the popular sonorous materials from all countries, (a source) intermediary to all people. For Villa-Lobos, the music of Bach comes from the astral infinity to infiltrate in Earth as folk music, and this cosmic phenomenon reproduces itself over the lands, subdividing itself over the various parts of the terrestrial globe, with a tendency to become universal7.

Villa-Lobos's imaginative remarks on the universality of Bach's music demonstrate his fascination for this music. If on one hand, he recreates and replicates, the mythological, cosmological and superhuman Bach figure of the nineteenth century, on the other, he also re-interprets the compositional techniques used by Bach, according to his own perception of these procedures. His attraction to Bach's music became an argument to provide the musical material and ideas for the Bachianas, despite the ethno-centered bias that such visionary supposition may suggest. However, as observed by Béhague (1994), what Villa-Lobos's intuitively perceived in the universality of Bach's music was the "clear affinities between certain contrapuntal textures and rhythmic procedures in Bach and those of certain aspects of Brazilian folk and popular music" (Béhague 1994, p. 105-106).

The series of nine Bachianas Brasileiras reflects in many aspects the adoption of Bachian musical allusions. For instance, many of these have among their movements a pair of Prelude and Fugue. The second and third movements of the Bachianas Brasileiras № 1 (1930) are a Prelude (Modinha) and Fugue, the latter called by the composer Conversa (or conversation). Bachianas № 7 (1942) is arranged as a suite containing a Prelude (Ponteio), Giga (Quadrilha Caipira), Tocata (Desafio) and Fugue (Conversa), and № 8 (1944) as a Prelude, Aria (Modinha), Tocata (Catira Batida) and Fugue, both works for orchestra. The last work in the series, Bachianas brasileiras №. 9, composed in 1945, is set originally for a cappella choir (and orchestrated for strings), and its movements are arranged as a Prelude and Fugue. Moreover, most of the movements in the Bachianas cycle present a cotitle that denotes the relationship to genres of Brazilian popular music.

\footnotetext{
7 "Bachianas Brasileiras - título de um gênero de composição musical criado de 1930 a 1945 para homenagear o grande gênio Johann Sebastian Bach. As Bachianas Brasileiras, em número de 9 suítes, são inspiradas no ambiente musical de Bach, considerado pelo autor como fonte folclórica universal, rica e profunda, com todos os materiais sonoros populares de todos os países, intermediária de todos os povos. Para Villa-Lobos, a música de Bach vem do infinito astral para se infiltrar na terra como música folclórica e o fenômeno cósmico se reproduz nos solos, subdividindo-se nas várias partes do globo terrestre, com tendência a universalizar-se" (Museu Villa-Lobos (1972), p. 187).
} 


\title{
3 - Bachianas Brasileiras № 1
}

\author{
In 1947, Villa-Lobos described Bachianas Brasileiras № 1 as follows:
}

The first bars of Bachianas brasileiras № 1 create, simultaneously, the typical Brazilian mood and a classic harmonic atmosphere. In $\mathrm{m} .7$ begins a serious and large melody, spiritualizing Bach's processes, without loosening the initial rhythm. The work's second part, Aria8 (Modinha) begins languid and smooth. Its main theme, constructed in the Aria form, in the manner of Bach, with a large and plaintive melody, it is followed by a Più Mosso section played by the second cellos stand with a sequence of marked chords and interwoven rhythmic cells, fast and exciting. This movement ends with the main melody played by a cello solo in pianissimo. The Fugue (Conversa), composed in the manner of Satiro Bilhar, an old carioca bohemian singer and Villa-Lobos's friend, describes a type of conversation among four players, where its instruments dispute thematic primacy in successive questions and answers, in a dynamic crescendo ${ }^{9}$.

The work is composed for Orchestra of Violoncelli and dates from $1930^{10}$. It presents three movements: I. Introduction (Embolada); II. Preludio (Modinha), and III. Fugue (Conversa). From Villa-Lobos's description of the work quoted above, I selected some characteristics that suggest elements of stylization, of neoclassicism, and of Brazilian popular music that, of course, imply intertextual references. These are: 1) typical Brazilian mood; 2) classic harmonic atmosphere; 3) spiritualizing Bach's processes; 4) Aria [Preludio], in the manner of Bach; 5) Fugue (Conversa). Thus, categorizing Villa-Lobos's identification of these topics, I opted to explore the following topics in the analysis: 1) Tonality: classic harmonic atmosphere; 2) Spiritualizing Bach's processes - Topics and learned style: chorale, Fugue d'école, and polyphonic melody; 3) Typical Brazilian mood, as given by the subtitle of each movement, Embolada, Modinha, and Conversa.

\footnotetext{
${ }^{8}$ In fact, the movement is titled Preludio(Modinha) and makes the pair with the subsequent Fugue (Conversa).

${ }^{9}$ Original text: Os primeiros compassos de Bachianas Brasileiras № 1 criam, simultaneamente, o ambiente típico brasileiro e a atmosfera harmônica clássica. No sétimo compasso aparece uma melodia grave e larga, espiritualizando os processos de Bach, sem perder o ritmo inicial. A segunda parte da obra, Ária (Modinha) inicia-se lânguida e pastosa. Seu tema principal, construído em forma de Ária, à maneira de Bach, com melodia larga e lamentosa, é seguido do Più Mosso confiado à estante segunda com marcha de acordes marcados e entrelaçados de células rítmicas, ligeiras e picantes. Este movimento termina com a melodia principal executada por violoncelo solo, em pianíssimo. A Fuga (Conversa), composta à maneira de Sátiro Bilhar, velho seresteiro carioca e companheiro de Villa-Lobos, descreve uma espécie de conversa entrequatro chorões, cujos instrumentos disputam a primazia temática, em perguntas e respostas sucessivas, num dinâmico crescendo (Museu Villa-Lobos 1972, p. 188).

${ }^{10}$ Lisa Peppercorn argues that the first movement may have been composed between 1936-38 because until 1936 only the second and third movements were played. The first performance of the whole work was in 1938 (See for example in Tarasti 1995, p. 182; and Wright 1992, p. 83-85).
}

\section{MUSICA THEORICA}

Revista da Associação Brasileira de Teoria e Análise Musical Journal of the Brazilian Society for Music Theory and Analysis @ TeMA 2017 - ISSN 2525-5541 


\subsection{Tonality: classic harmonic atmosphere}

The first movement, Introduction (Embolada), presents a peculiar formal design. It has a sequence of distinct sections, rhapsodic likewise, organized with a succession of different themes, tonal regions, and textures. The overall formal design suggests, according to its tonal plan, a formal scheme of A-B-A'. The first section is tonally centered around $C$ minor, but wandering around $G$ minor, $B$ flat major, E flat major, and F minor. Besides the main theme in $\mathrm{C}$ minor, each of these regions corresponds also to a subsection that presents different thematic material. The second section, B, is entirely centered in F major, and it presents an elaboration of previous thematic material. The last section, $\mathrm{A}^{\prime}$, tonally returns to the tonic, $\mathrm{C}$ minor, but presents a large subsection in $\mathrm{E}$ flat major with a subsidiary theme derived from the main theme. Finally, the work closes in $\mathrm{C}$ minor.

Hence, these tonal regions, centered in C minor, corroborate the sense of a classic harmonic atmosphere. It is interesting to observe that in the first section in $\mathrm{C}$ minor, the tonic does not maintain a control over its surrounding regions as a major tonic would exert. Even the last section also fluctuates between $\mathrm{C}$ minor and E flat major. However, the central section (B) is stable in F major. In Table 1, the dark grey shadowed area indicates the tonic and around it, are the tonal regions directly related to it. In addition, B flat major, which is treated as a dominant of $\mathrm{E}$ flat, and $\mathrm{F}$ major, which is set apart as the tonic of the central section (B) of the movement.

\begin{tabular}{|c|c|}
\hline \multirow{3}{*}{$\begin{array}{l}\text { B flat major } \\
\text { E flat major }\end{array}$} & $\mathrm{G}$ minor \\
\hline & $\mathrm{C}$ minor \\
\hline & F minor \\
\hline
\end{tabular}

Table 1: Tonal relationships in C minor

The beginning of the first section, illustrated in the reduction ${ }^{11}$ in Example 1, presents the first theme characterized by the arpeggio of $C$ minor in $\mathrm{mm}$. 7-19. It is followed in $\mathrm{m}$. 20 by the introduction of B natural that produces the Dominant function ( vii $^{\circ}$ ) that resolves in the tonic (i) in the subsequent bar. This characterizes the theme as tonally stable and as a tonic prolongation (indicated by the prolonged beams). The introduction of a secondary dominant (V/iv) in $\mathrm{m}$. 39 , gives impulse to the subsequent regions that gravitate around the tonic minor.

\footnotetext{
${ }^{11}$ It is important to explain that the analytic reductions are intended as structural summaries of sections of the work and do not intend to represent a Schenkerian analysis despite the fact they are inspired by. The prolonged beams represent harmonic prolongations.
} 


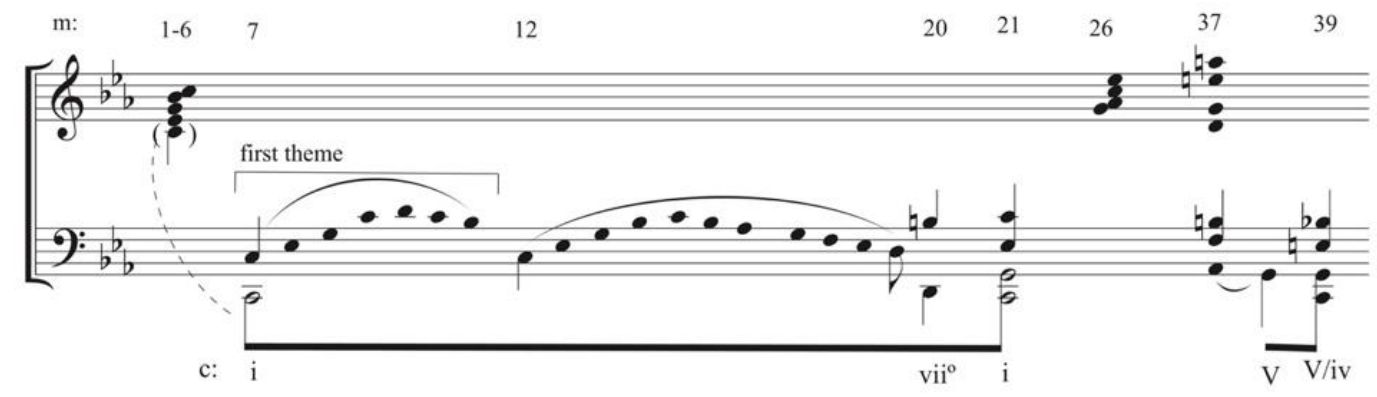

Example 1: Reduction of mm. 1-39

In Example 2, the segments show the tonal regions of the first section (A). Sequential passages (shown by the interruptions in the graph) in mm. 47-49, 5860 and 71-88, explore the directly related regions of $\mathrm{G}$ minor, $\mathrm{C}$ minor and $\mathrm{B}$ flat major. The interruptions in the music are melodic segments played by alternating solo cello. However, in $\mathrm{mm}$. 71-88 a pedal point in F functions as the dominant to B flat major reached in $\mathrm{m} .89$, which, in turn, is reinterpreted as the dominant of E flat major in m. 95. Between mm. 105-122, E flat major is prolonged as a region, but it changes to $\mathrm{C}$ minor and later to $\mathrm{F}$ minor, already preparing for the F major of the central section. The tonal stylization in the first section of the work adopts a change of tonal regions mainly by fifths, i.e. according to the circle of fifths. In this way, it is an imitation of a tonal technique of classical music.
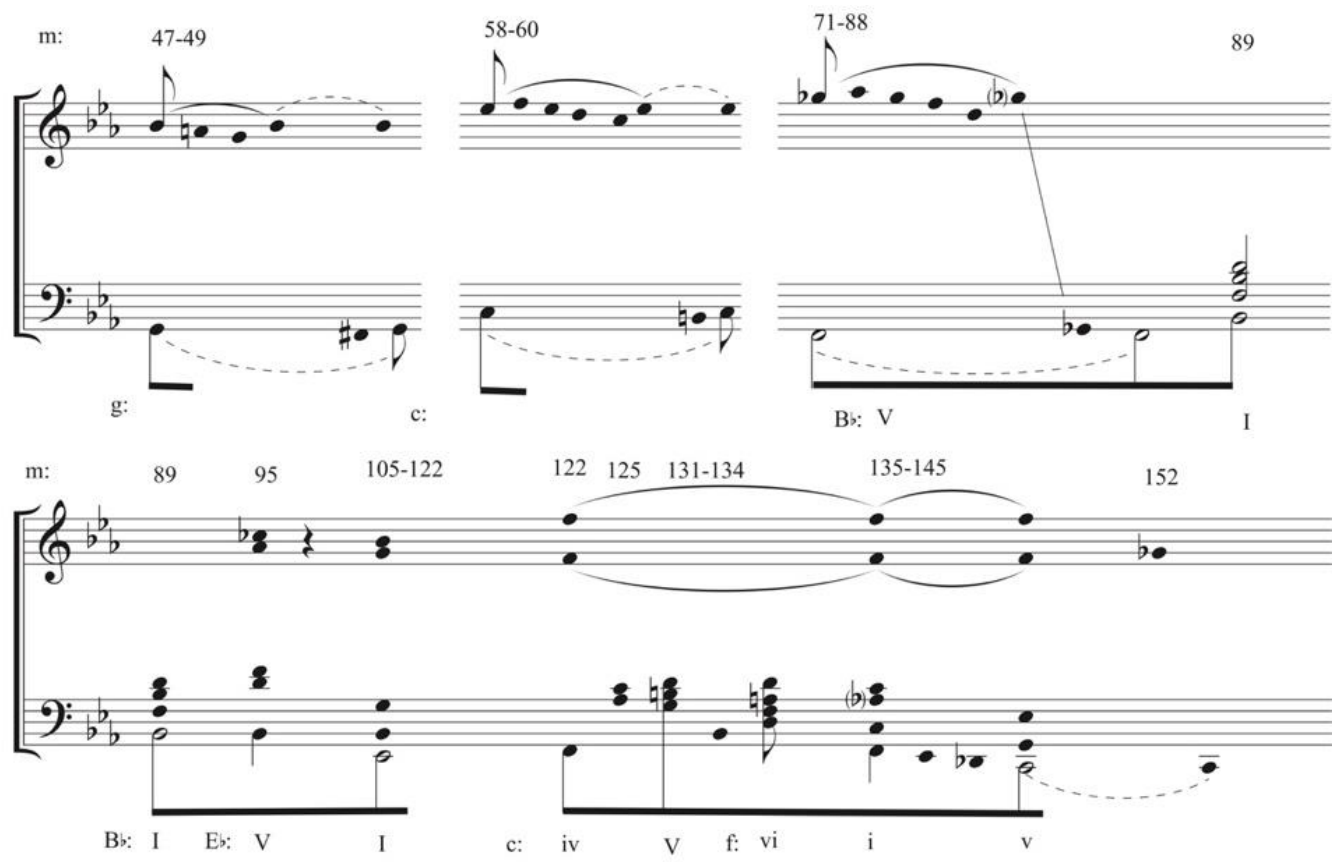

Example 2: Reductions of mm. 47-49; 58-60; 71-89; and 89-152 
The central section (B) (mm. 159-248), in F major, presents a new theme, but more important at this time, it is tonally stable, beginning and ending in $\mathrm{F}$ major. The harmonies in this section are centered around the tonic (I), the dominant $(\mathrm{V})$ and a secondary dominant $(\mathrm{V} / \mathrm{V})$. There are no secondary regions, and therefore, the whole section is emphasized by its stable tonal characteristic (see Example 3).

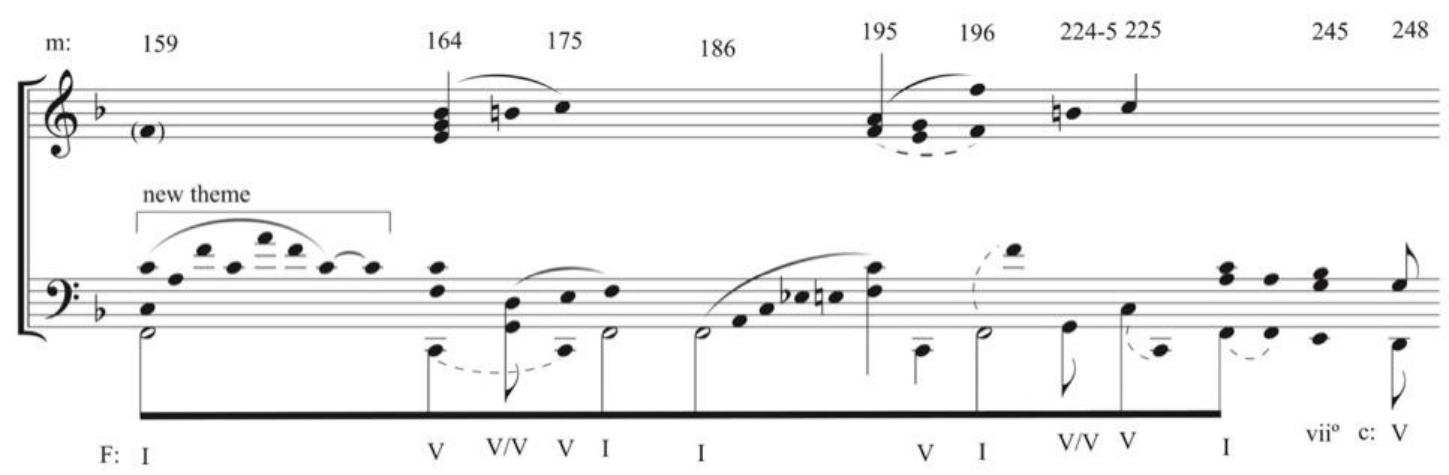

Example 3: Reduction of mm. 159-248

The last section may be subdivided into two subsections, as shown in Examples 4 and 5. The first subsection presents a prolongation of $\mathrm{E}$ flat major after returning briefly to the tonic, $\mathrm{C}$ minor. However, the region of $\mathrm{E}$ flat major dominates and is confirmed by the tonic prolongation between mm. 257-292. Also important is the new subsidiary theme presented in E flat major, indicated by the square bracket in the example, and its thematic correspondence in the second part of the example. It is noticeable that the thematic repeat is harmonized also in E flat major but it emphasizes C minor in mm. 275-276, and in its final V-I cadence the E flat major chord presents a sixth added (m. 289-292), causing ambiguity in its tonal centricity. 

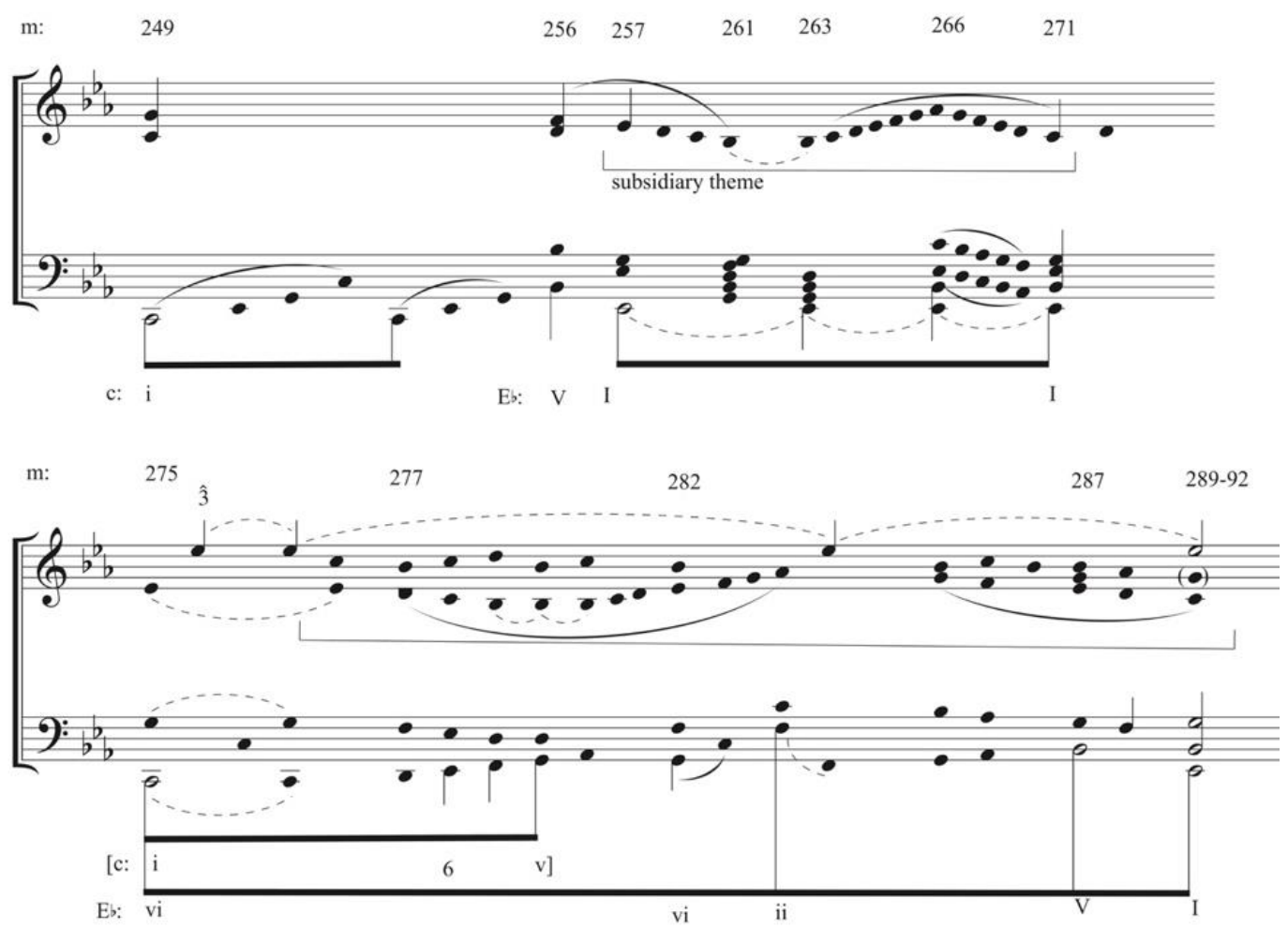

Example 4: Reduction of mm. 249-292

The final subsection, returns to $\mathrm{C}$ minor and recapitulates the main theme. The final cadence, ii $^{\circ}-\mathrm{V}-\mathrm{I}$, confirms the tonic and adds a Picardy third, a mannerism of Baroque music.

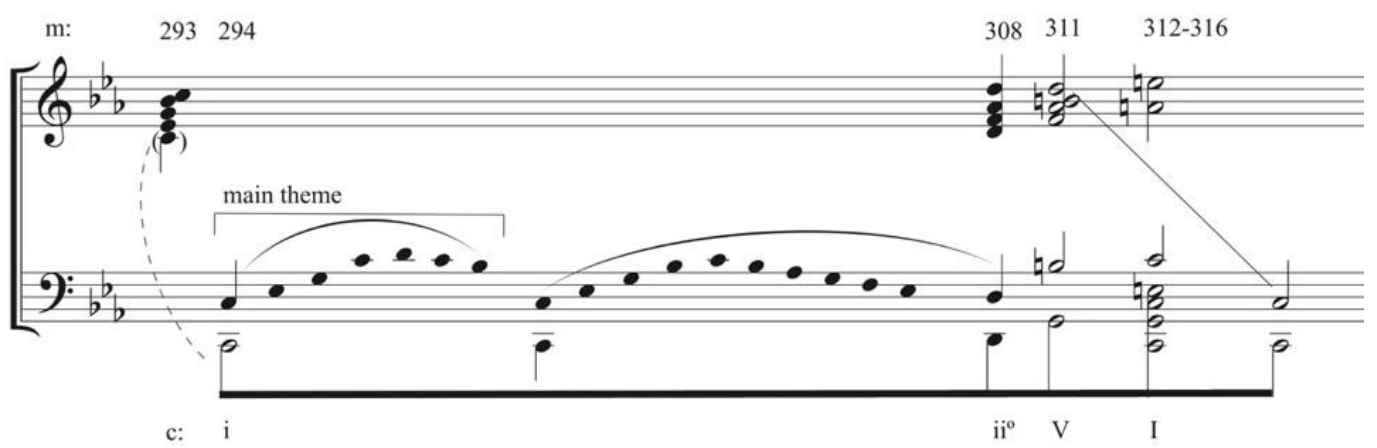

Example 5: Reduction of mm. 293-316

Summarizing, in the first movement the references to classic tonality and its stylization are consistent and demonstrate one of the main characteristic features of the work. Confirming the tonal characteristics of the piece, the graph in Example 6 illustrates a further reduction of the entire movement. It is noticeable that the fundamental line $(\hat{5}-\hat{4}-\hat{3}-\hat{2}-\hat{1})$ is not evident. In fact, 
the primary note $(\hat{5})$ may be implied and related to E flat major only in $\mathrm{m} .105$, the $\hat{4}$ is related to the large section in F major, $\hat{3}$ to E flat major/C minor (m. 257). The final cadence characterizes $\hat{2}\left(\mathrm{~d}^{2}\right)$, in $\mathrm{m}$. 311, proceeding to $\hat{1}$ (c) two octaves below, but there is a detour to natural $\hat{3}\left(\mathrm{e}^{2}\right)$ (E natural) characteristic of the Picardy third of the last tonic chord.

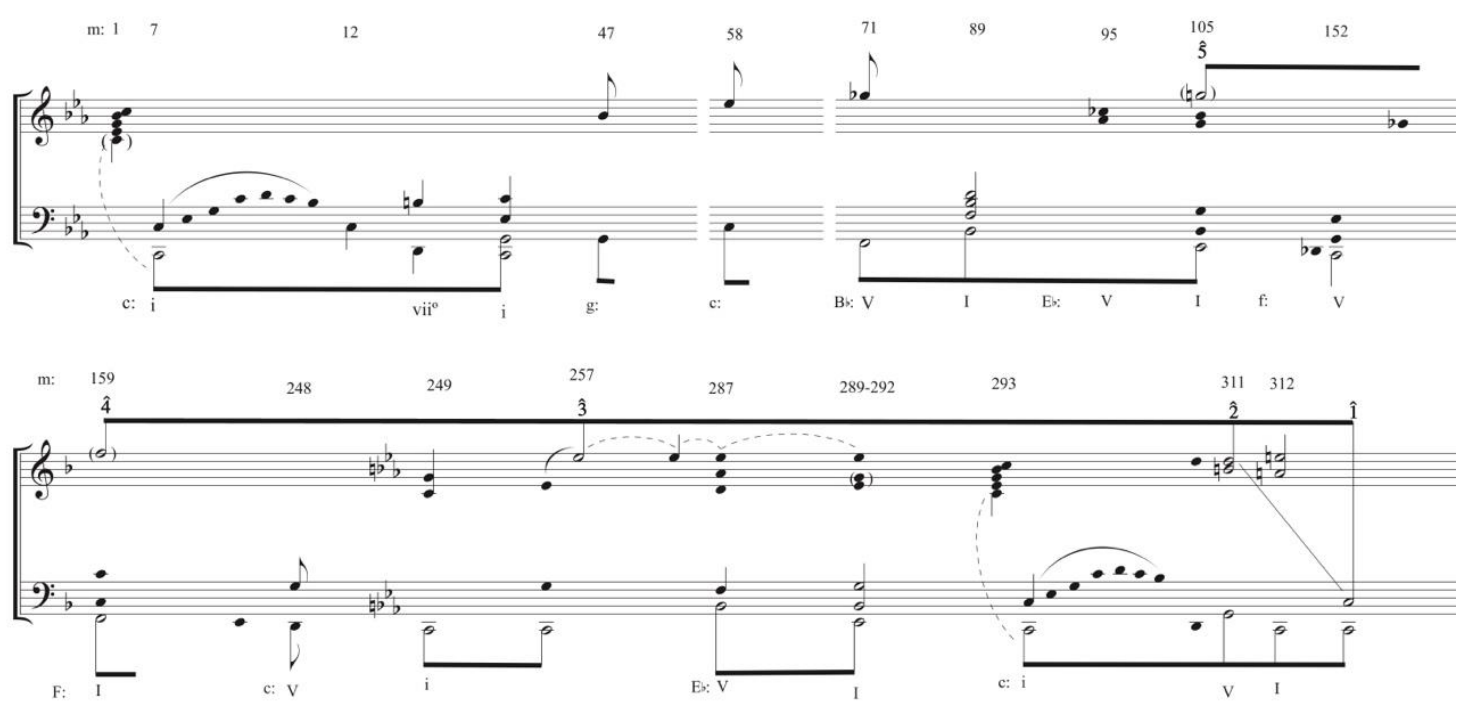

Example 6: Middleground synopsis

In the second movement, Preludio (Modinha), Villa-Lobos preserves the sense of a classic tonal atmosphere despite the passages of highly chromatic material. Example 7 illustrates the beginning of the second movement, an introduction in which the tonality floats between $\mathrm{D}$ minor and $\mathrm{F}$ major. In the example, mm. 1-13, may be summarized by the graph. In $\mathrm{m}$. 1, the tonic (D minor) is already presented with chromatic passing notes, $F$ sharp (F\#) in the bass line and $\mathrm{E}$ flat $\left(\mathrm{eb}^{1}\right)$ in the melody. The latter note is emphasized in $\mathrm{m} .2$ as an internal neighboring note to $\mathrm{D}\left(\mathrm{d}^{1}\right)$ until reaching the stable $\mathrm{D}$ minor triad in $\mathrm{m}$. 5. In spite of the modal quality of the passage - a Phrygian mood - the tonic chord is reached and metrically emphasized in $\mathrm{m}$. 5. The subsequent segment beginning in $\mathrm{m}$. 6 leads to the dominant of $\mathrm{F}$ major $\left(\mathrm{V}^{13}\right)$ in $\mathrm{mm}$. 7-8. The final segment of the introduction establishes $\mathrm{F}$ major through its arpeggio, despite the chromatic passing notes, but it also directs back to D minor, established in the presentation of the main theme of the Modinha in the next section (see Examples $12 \mathrm{a}-\mathrm{c})$. 


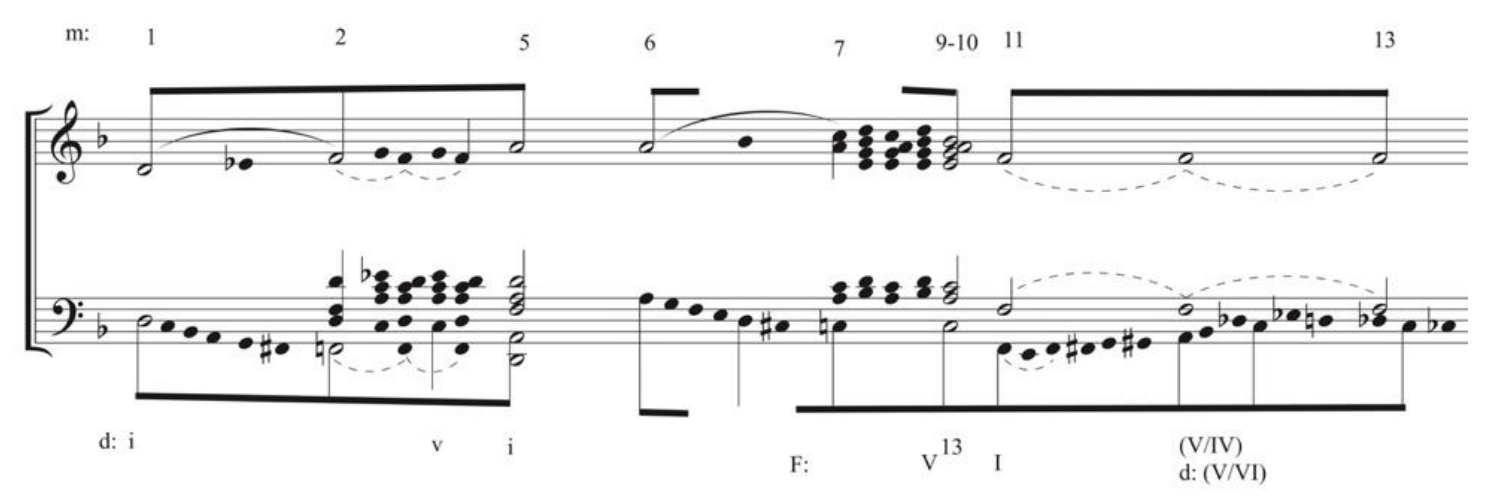

Example 7: Reduction of mm. 1-13, second movement

Another passage, in mm. 25-27 (Example 8), centered in D major, begins with a prolongation of $\mathrm{D}$ major by its neighboring chord. The passage derives from an incomplete octatonic collection. Measures 27-29 address a hazy harmonic area. No tonality may be inferred from it, in fact, the function of this passage is to create tension that will be lightly released in $\mathrm{m} .33$ when the F sharp minor triad with added ninth is reached. A final passage prolongs the $\mathrm{F}$ sharp and A natural mm.35-36 by the neighboring dissonant notes E flat and F natural, making up an incomplete octatonic collection, until it reaches the consonant D minor in mm.37-38.

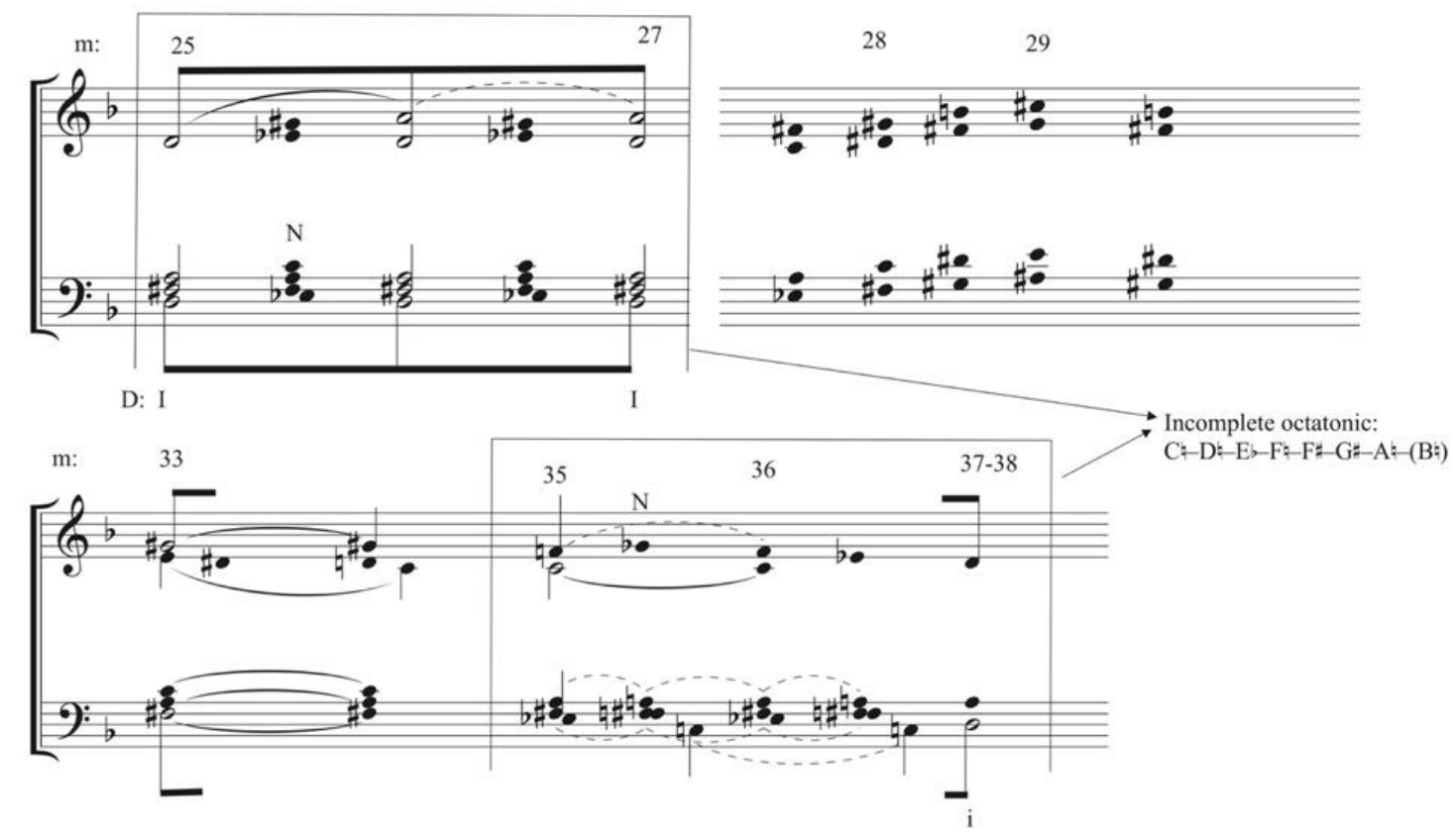

Example 8: Reduction of mm. 25-38, second movement

Corroborating the classic harmonic atmosphere even more, the fugue also presents harmonic details that allude to traditional tonality. The first illustration 
shows the use of cadential gestures as a means to close sections. Example 9a, illustrates in $\mathrm{m}$. 30 the interrupted cadence to the dominant of $\mathrm{G}$ minor. The voice leading, in $\mathrm{G}$ minor tonality, respects the natural 6th degree that progresses to the leading note, F sharp, and then resolves to the tonic. The observation here concerns the resolution in the upper voice while the dominant chord still sounds in the bass. However, the resolution is felt to be more conclusive because of the presentation of the fugue subject in the following $\mathrm{m}$. 31. The second illustration, in Example 9b, shows the first example of a passing augmented sixth chord as a concluding dominant to a tonic function. In $\mathrm{m}$. 38 the progression of $\mathrm{ii}^{7}-6^{+}-\mathrm{i}$ asserts the $\mathrm{C}$ minor goal and closes the section, but immediately it begins the stretto section.
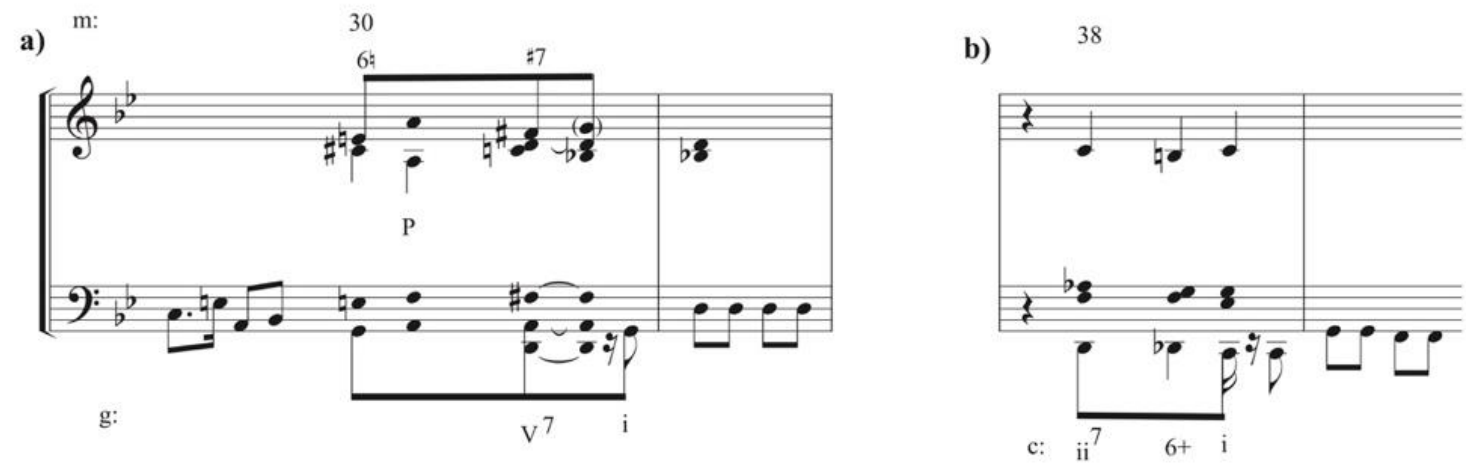

Example 9a, b: Reduction of mm. 30-31 and 38-39, third movement

The passage between mm. 47-59 in Example 10 represents an extended cadential episode in the Fugue. The passage projects a prolongation of the dominant of $\mathrm{C}$ minor between $\mathrm{mm}$. 47-49, while the resolution is reached in $\mathrm{i}^{13}$ in m. 50. Follows, in mm. 50-54, a passage that culminates in the enharmonic reinterpretation of $\mathrm{C}$ flat to $\mathrm{B}$ natural, subsequently functioning as the leading note to $\mathrm{C}$. The final cadence in the episode presents the bass line of D natural Dflat - C natural, that is, $\mathrm{V} 4-6^{+}-\mathrm{i}(\mathrm{mm} .55-59)$, again with the augmented sixth chord as a main dominant to the tonic, despite its passing note character. 


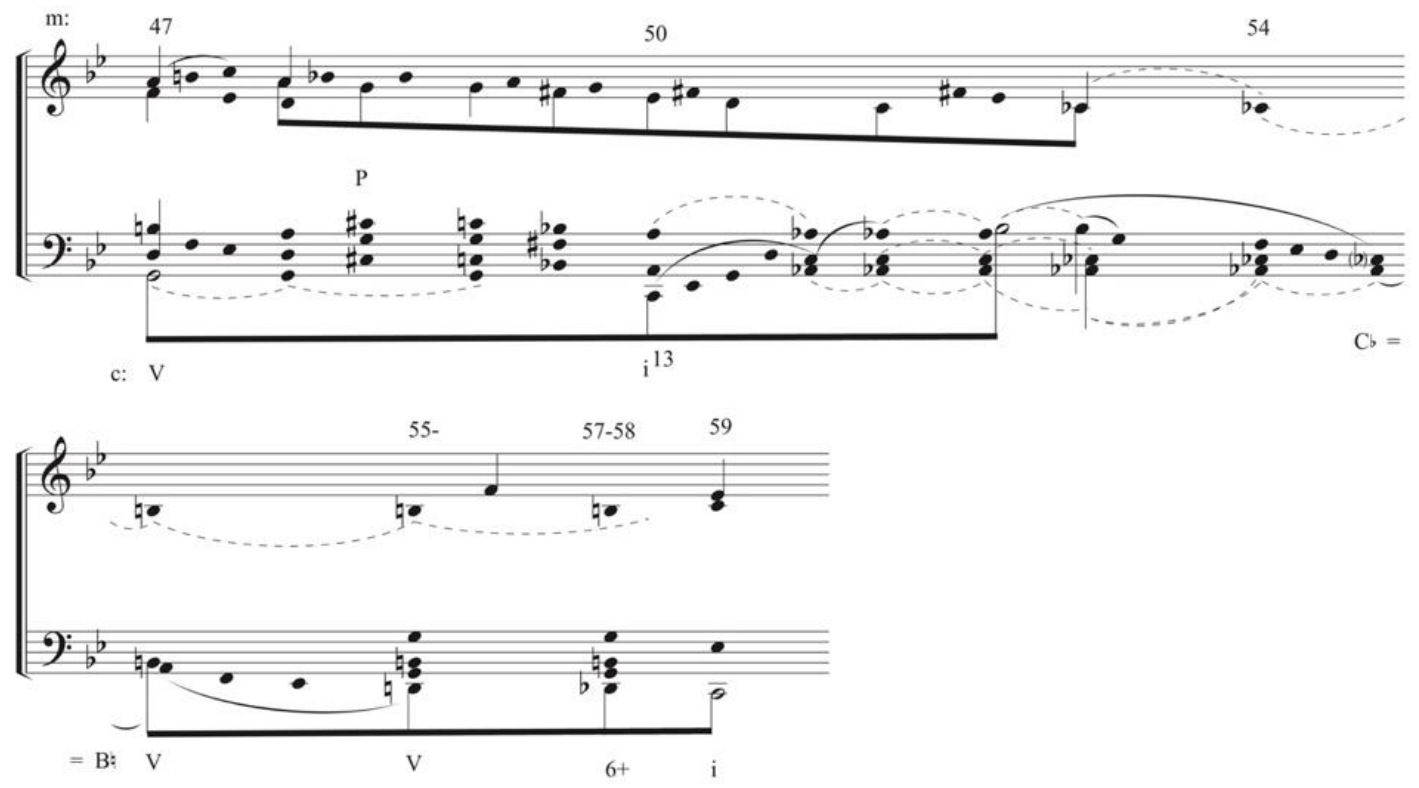

Example 10: Reduction of mm. 47-59, third movement

Finally, in Example 11, the final cadence in the third movement shows a cadence ii-V-I in B flat major. Noticeable is the internal voice descending line of $\hat{5}-\hat{4}-\hat{3}-\hat{2}-\hat{1}$ that finalizes the cadence.

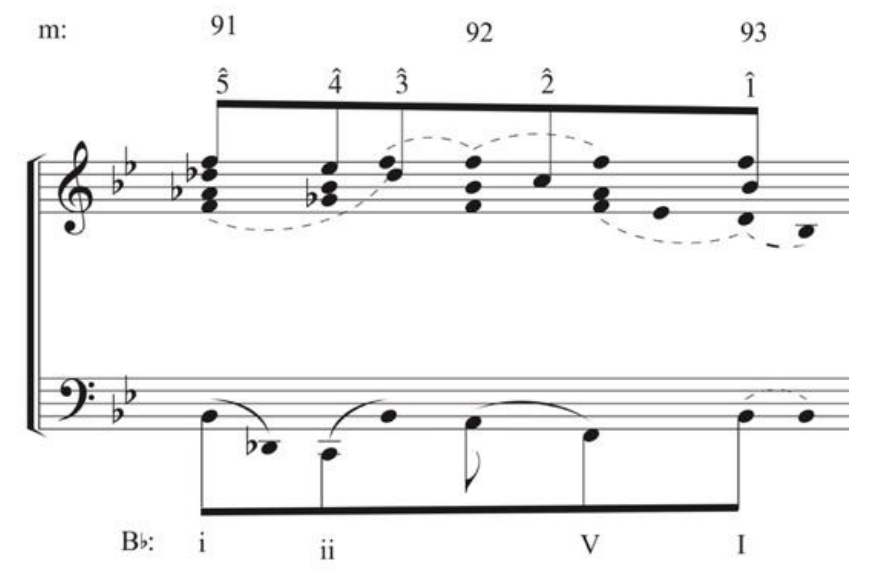

Example 11: Reduction of mm. 91-93, third movement

\subsection{Spiritualizing Bach's Processes}

\subsubsection{Topics and learned style: Chorale}

Hatten defines that "a topic is a familiar style type with easily recognizable musical features" (Hatten 2014, p. 514). Complementing this definition, Klein (2005) addresses the way to activate the recognition of topics. He writes that topic 
is "a code that associates a conventional label with a constellation of musical signs. Topics of musical discourse are types $[\ldots]$ that are instanced by tokens" (p. 140). The triggering of cognitive association to certain figures of traditional music certainly depends on the cultural background of the listener, however composers often use this procedure by way of specific musical figures, which often allude to musical styles of the past, in order to explore intentional (or unintentional) intertextual components of their music. The intention is to relate the music to a former style. Ratner (1980) explains that "some of these figures were associated with various feelings and affections; others had a picturesque flavor. They are designated here as topics - subjects for musical discourse. Topics appear as fully worked-out pieces, i.e., types, or as figures and progressions within a piece, i.e., styles" (p. 9). In order to analyze music from the viewpoint of topics, Agawu (2009) argues that it is necessary to access a "prior universe made up of commonplaces of style known to composers and their audiences" (p. 43). Indeed, the context of composer and his work is important in order to establish what to emphasize in a specific analysis. In other words, it is important to define categories of topics specific to a musical work, a group of works, or a music style. In this sense, the topical vocabulary proposed by Dickensheets (2012) advances in the identification of new topics and reinterpretation of known topics. She categorizes her lexicon into topics, styles and dialectics, the latter are defined as "assemblages of musical gestures and other topics that, when used together in conjunction, define a specific dialect, one that typically calls up strong extramusical associations" (p. 124-125). Both, Agawu and Dickensheets, propose topic analysis to the nineteenth-century music, expanding to the twentieth-. However, Agawu points to the difficulties of acceptance of a historical continuity between the consolidated topic theory in eighteenth-century music to the nineteenth-, despite the many adaptations by composers. Finally, Horton (2014) summarizes that "nineteenth-century composers also devised fresh topics, which as facets of a new style are conceptually opposed to topics associated with the classical past" (Horton, p. 643).

In the Bachianas, Villa-Lobos also alludes to former styles of music, not only to those related to Bach's music, but also to those related to traditional Western and Brazilian music. Therefore, Villa-Lobos devised a type of amalgamation between eighteenth- and nineteenth-century topics and newly devised topics that suits to his own compositional needs. In fact, Villa-Lobos alludes to topics pertaining to learned style of eighteenth-century music, in the narrow and broad sense defined by Chapin (2014). In its narrow sense, learned style refers to techniques of imitative counterpoint and, in particular, the fugue. In a broader sense, the style comprises species counterpoint, the chorale, and the improvisatory complexities of the fantasy (p. 301). Therefore, it is important to observe that by alluding to a mixture of topics of learned style and Brazilian 
music, Villa-Lobos devises his Bachianas as in terms of a musical manifestation of an ethos, i.e. the characteristic spirit of a musical era associated to his beliefs of national Brazilian music.

In this way, it can also be identified specific topics and styles throughout the entire cycle of Bachianas. One of these topics - the chorale figuration - is frequently found throughout the individual pieces of the cycle. Villa-Lobos refers to chorale style in his description of some of the Bachianas. For instance, he describes a section in the Fantasia from Bachianas № 3 as presenting a theme with a circle of fifths sequence accompaniment in chorale style (Museu Villa-Lobos (1972) p. 189). Similarly, he describes another passage in the fugue from Bachianas № 9 pertaining to the same style (p. 197). These passages illustrate a recurring stylization in different passages in the Bachianas' cycle. The characteristics of this topic is to present an important theme with the accompaniment of harmonic progression by fifths, and simple homophonic texture.

In Bachianas № 1 there are instances in which the choral writing is stylized and intended to present an important theme of the work. In the second movement, Preludio (Modinha), there are two examples of this type of intertext. The main theme of the movement is harmonized as a four-voice chorale texture and illustrated in Example 12a (the melody is simplified). The simple diatonic harmonization asserts $\mathrm{D}$ minor as tonic. The sequence of fifths that predominates in $\mathrm{mm} .14-16$ leads to the dominant $\left(\mathrm{V}^{7}\right)$ in $\mathrm{m}$. 17, and the final cadence in $\mathrm{mm}$. 19-20 presents the $\mathrm{V} / \mathrm{V}$ through the passing augmented sixth to $\mathrm{V}^{7}$ resolving to the tonic in m. 20. A second instance of chorale texture occurs with the presentation of the main theme in augmentation. It is harmonically sequential and centered in $\mathrm{G}$ minor. Example $12 \mathrm{~b}$ (the melody is also simplified) shows that the harmonic structure is mainly diatonic despite the few chromatic passing notes in the melody and the secondary dominant of the subdominant (V/iv) in $\mathrm{mm}$. 45-46. In addition, the recapitulation of the main theme in augmented form also alludes directly to common procedure in Baroque music (Example 12c).

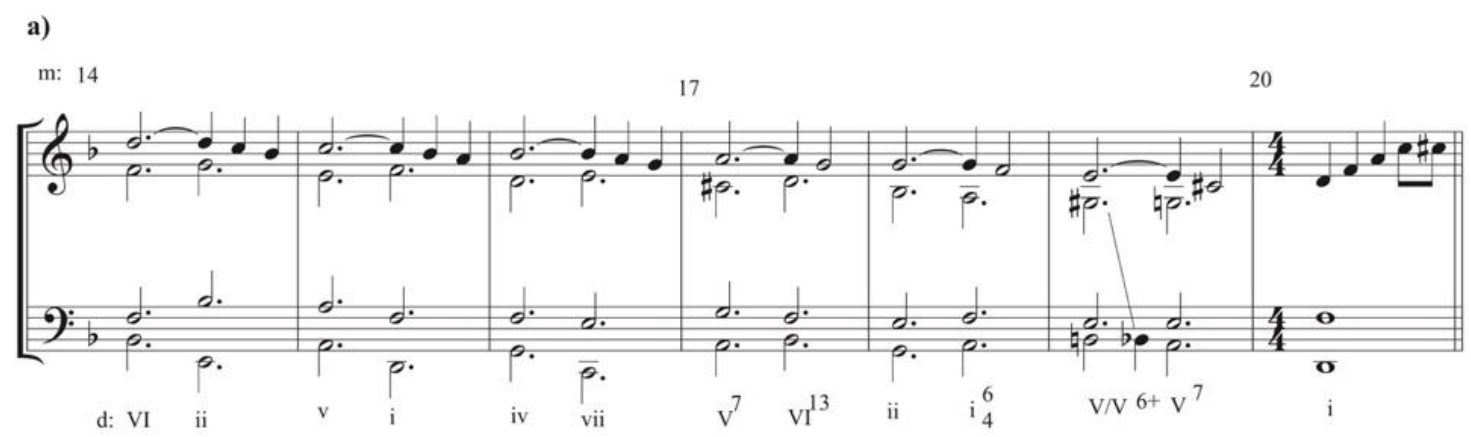


b)

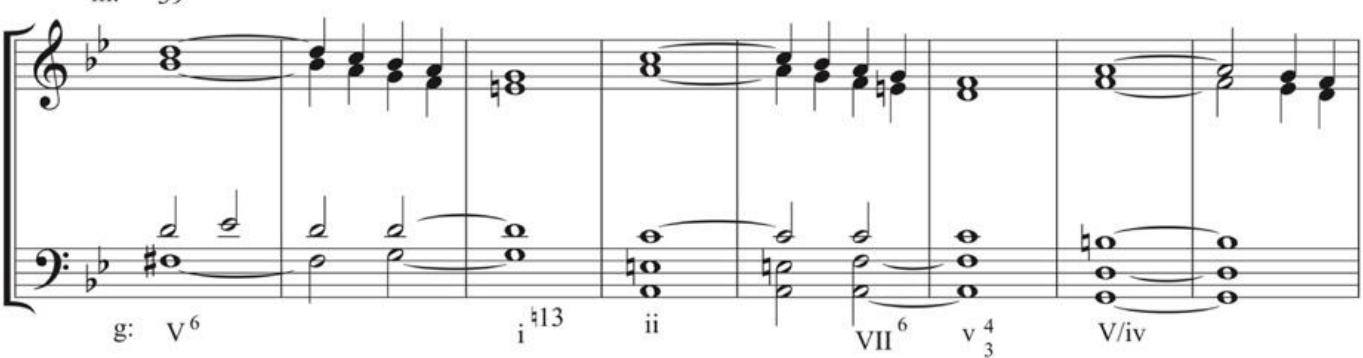

50

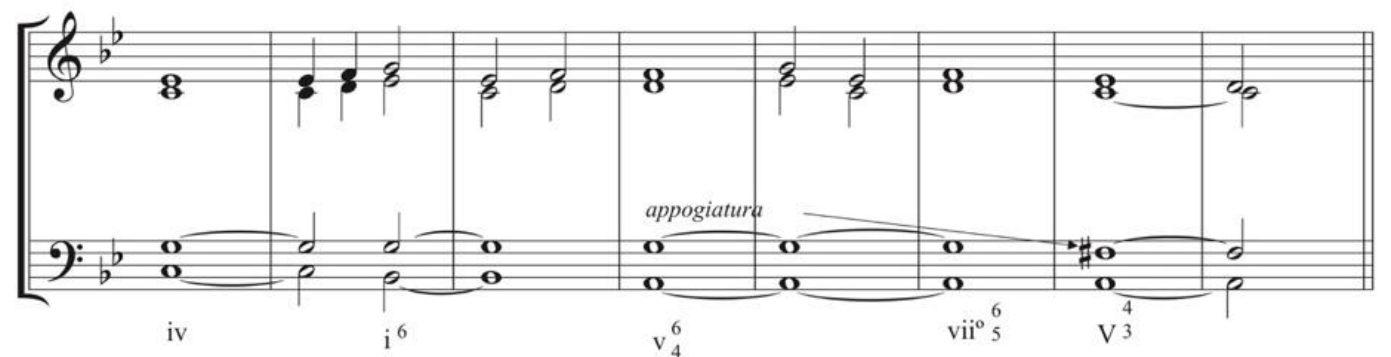

c)
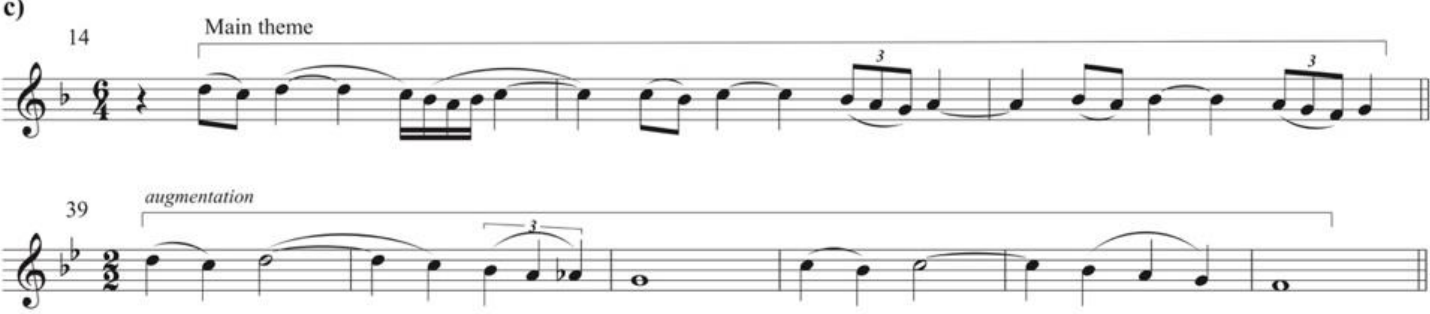

Example 12: a) reduction of $\mathrm{mm}$. 14-20, second movement; b) reduction of mm. 39-54; c) main theme and augmented form, second movement

Another instance of allusion to a Bachian choral style occurs in the first movement. In this example, the choral stylization is organized differently, as shown in Example 13. Firstly, the texture presents parallel chords with parallel fifths in the bass and a high pedal point in F, guaranteeing a compact sonority of homophonic choral texture. Tonally, the passage is centered in F minor and A flat major. The F minor, because of the lack of the leading note (E natural), acquires an Aeolian mood at the end of the passage. However, A flat major is clearly established by the IV - V - vii ${ }^{\circ}$ - I cadence in mm. 140-142.

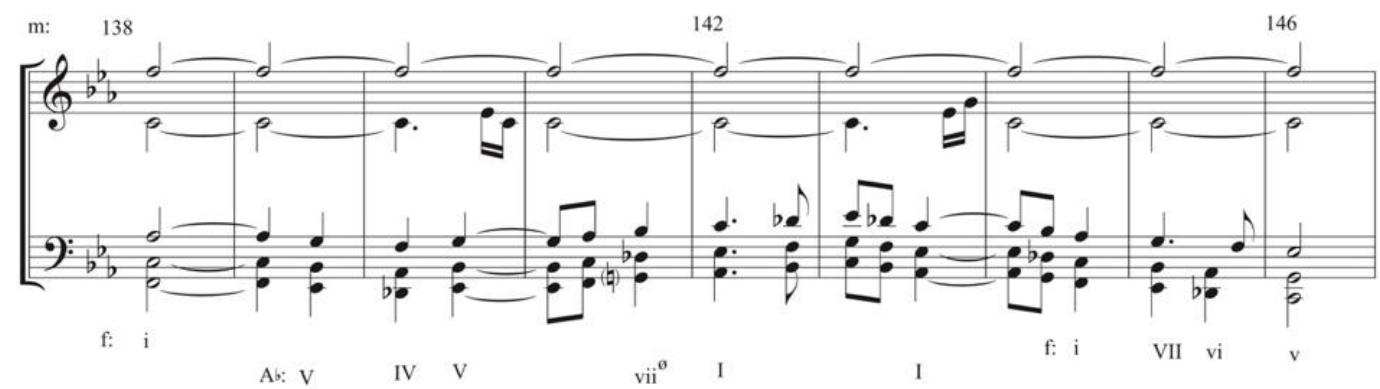

Example 13: Excerpt of mm. 138-146, first movement 


\subsubsection{Topics - learned style: Fugue d'école}

In 1920, Darius Milhaud, in his article "Brésil" for the Revue Musicale, states that Vincent D'Indy and the Schola are models for Argentinian and Chilean music, in Brazil, there is, clearly, a debussyan and impressionistic orientation (1920, p. 60-61). Despite of Milhaud's identification of the tendencies in Brazilian music of the time, the mention of D'Indy and the Schola Cantorum is of particular interest. In 1941, Villa-Lobos stated the importance of D'Indy's Cours de Composition Musicale (1903) as an important reading during his formative years, placing it in 1914. ${ }^{12}$ In fact, Nóbrega (1969) reported in 1955 that Leão Veloso brought a copy of D'Indy's treatise from Paris and gave it to Villa-Lobos during the 1910s (p. 14). This is corroborated by Villa-Lobos's music itself. For example, his music from the 1910s (Trios 1 and 2, Symphonies 1 and 2) show a tendency towards cyclic form.

In addition to D'Indy's treatise important contribution to Villa-Lobos theoretical formation, André Gédalge's Traité de la fugue (Paris, 1901) may be acknowledged as corroborating Villa-Lobos view of fugues. In his treatise, Gédalge lists eight structural components of a fugue d'école (school fugue) which coincide to the structural components listed by D'Indy (1903, v. 2/1, p. 3764) - these are: 1) the subject; 2) the answer; 3) one or more countersubjects; 4) the exposition; 5) the counter-exposition; 6) the episodes; 7) the stretto, and 8) the pedal point. It would not be a surprise if Villa-Lobos adopted and adapted these normative elements to his fugue in the Bachianas № 1. Even though Villa-Lobos's fugue does not conform to a Bachian fugue or a fugue d'école, it is organized according to the structural sections (elements) proposed by Gedalge and D'Indy. In fact, it represents a type of stylization in which elements of fugue are adapted to the composer's own compositional needs, thus replicating the eighteenth- and nineteenth-century models of topics and in particular learned style topic.

In the perspective of neoclassicism, fugues in general were brought back into favor during the 1920s and 30s. Examples are Stravinsky's fugue in the Symphony of Psalms (1930), Bartók's fugue in his Music for Strings, Percussion and Celesta (1936), and examples that follow along the line of J. S. Bach's Well Tempered Clavier are Hindemith's Ludus Tonalis (1942) and Shostakovich's 24 Preludes and Fugues (1950-51). ${ }^{13}$

Villa-Lobos describes the fugue of Bachianas № 1 as a type of conversation (Conversa), a "chit-chat", between four chorões (choro players) in which the instruments dispute thematic primacy in successive questions and answers. Perhaps this is the reason why Villa-Lobos had opted to composed a type of "informal" fugue, that is, a fugue with an uncommon disposition of its structural

12 See Corrêa do Lago, 2010, p. 30-61.

13 See Walker2001, p. 330-331. 
sections, despite the correspondence to the sections of the fugue d'école. Table 2 shows the formal segmentation of the fugue.

\begin{tabular}{|l|c|l|l|}
\hline Section & measures & \multicolumn{1}{|c|}{ tonality } & \multicolumn{1}{|c|}{ characteristic } \\
\hline Exposition 1 & $1-16$ & G minor $\rightarrow$ E flat major & \\
\hline Episode 1 & $17-30$ & E flat major $\rightarrow$ G minor & $\begin{array}{l}\text { CS in augmentation } \\
\text { S modified }\end{array}$ \\
\hline $\begin{array}{l}\text { Exposition 2 } \\
\text { Sequential passage }\end{array}$ & $31-8$ & G minor $\rightarrow$ C minor & \\
\hline $\begin{array}{l}\text { Exposition 3 } \\
\text { Stretto1 } \\
\text { Stretto 2 } \\
\text { Sequential episode }\end{array}$ & $39-43$ & C minor $\rightarrow$ G minor & \\
\hline Episode 2 & $44-6$ & G minor & Pedal point \\
\hline Exposition 4 & $59-65$ & C minor $\rightarrow$ C minor $\rightarrow$ G minor & CS primacy \\
\hline Episode 3 & $66-74$ & D minor $\rightarrow$ E flat major & $\begin{array}{l}\text { Double fugue } \\
\text { B flat pedal point }\end{array}$ \\
\hline
\end{tabular}

Table 2: Formal segmentation of Fugue, third movement

Example 14a shows the fugue subject beginning in the dominant harmony ( $\mathrm{G}$ minor: $\mathrm{V}, \mathrm{m} . \mathrm{1}$ ) followed by its answer in the tonic ( $\mathrm{G}$ minor: $\mathrm{i}, \mathrm{m} .4 \mathrm{ff}$.$) . In$ Example 14b the subject is presented around $\mathrm{E}$ flat major and $\mathrm{C}$ minor (in $\mathrm{m} .9 \mathrm{ff}$.), that is, G minor: VI and iv. Finally, in Example 14c, the subject is presented in F minor in $\mathrm{m} .13$ (ii of $\mathrm{E}$ flat major), and establishing $\mathrm{E}$ flat major through its dominant in $\mathrm{m} .14$ ( $\mathrm{V}$ of $\mathrm{E}$ flat major). The main countersubject is presented only in mm. 9 and 13 (shown in Examples 14b and c); and, in Example 14d, its augmentation in $\mathrm{m} .17$ delineates an arpeggio of the Dominant seventh $\left(\mathrm{V}^{7}\right)$ of $\mathrm{E}$ flat major. In fact, this presentation produces the cadential movement towards $\mathrm{E}$ flat major in m. 18.

Episode 1, which follows in $\mathrm{mm} .18-30$, presents the subject, but the main countersubject predominates in the section. The second exposition returns to the tonic in $\mathrm{m}$. 31, but it is soon interrupted by the sequential passage shown in Example 15a. The passage projects a circle-of-fifths-sequence: D minor-A majorG minor-C major-F minor-B flat major-E flat major-D minor-D flat augment 6th-C minor. The following section, in Example 15b, is characterized by the presentation of two stretti. The second stretto returns to the tonic and progresses to a "type" of sequential episode in mm. 47-59. Despite of the great variation of chronological events in the fugue until this point, all of these events configure structural elements of a fugue. They also constitute elements of intertextuality, and of relationship to neoclassicism, to learned style, and to a stylization of Bach's music. In the section in mm. 66-74, Exposition 4, the composer alludes to another fugue treatment: the double fugue. 

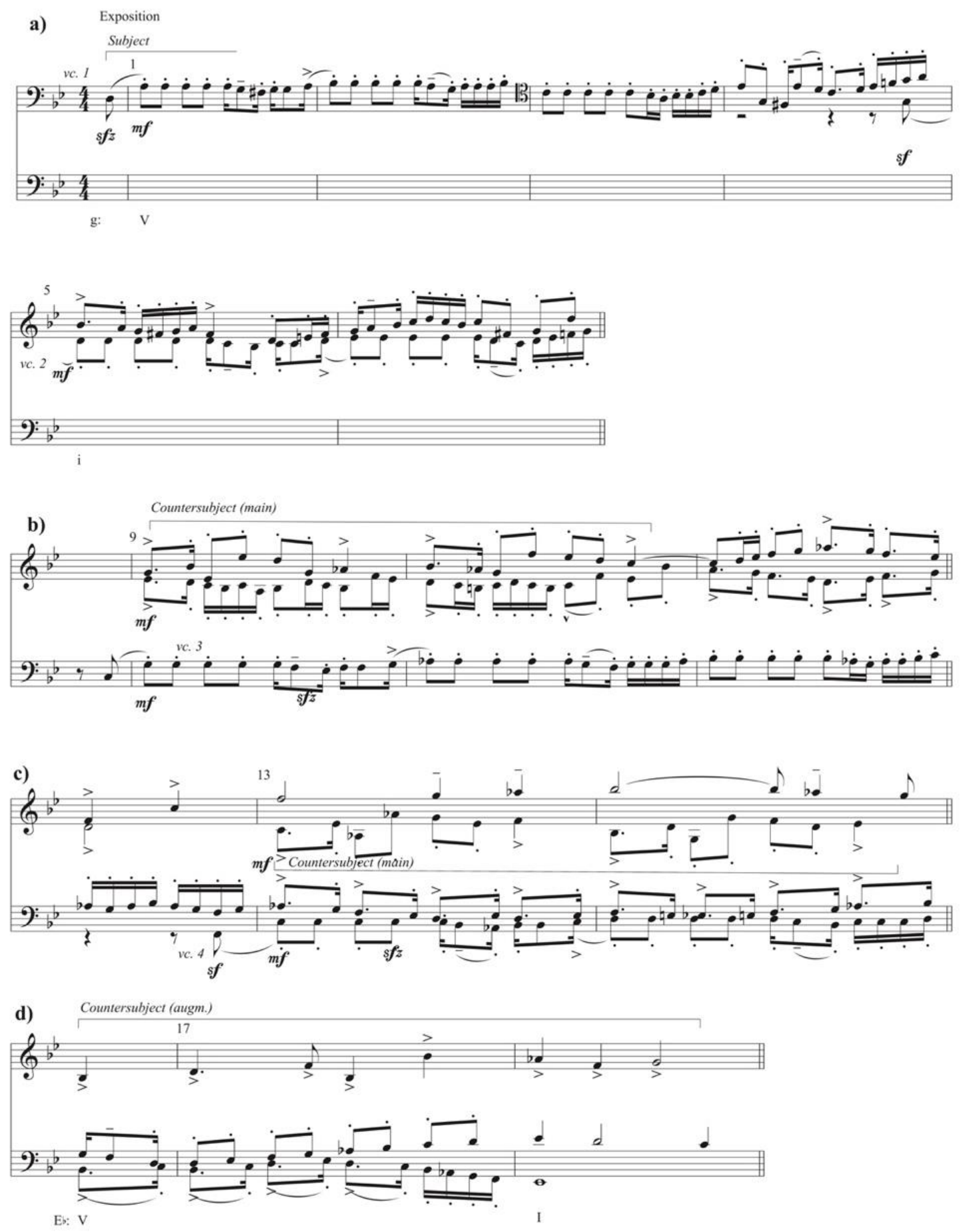

Examples 14 a-d: Presentations of fugue subject and countersubject, third movement

Example 15c shows an excerpt from the allusion to double fugue in which the subject is presented in cello 4 along with a new superposed subject in cello 2 (see mm. 66-67) and then in mm. 68-69 the subject is presented again in cello 1 at the same time with the new subject in cello 4. There is no development, or elaboration, of this idea suggesting only a reference to a fugue technique, while at this point of the work, i.e., its final Exposition, Villa-Lobos presents the subject 
within a sophisticated technique, asserting his ability for counterpoint techniques.
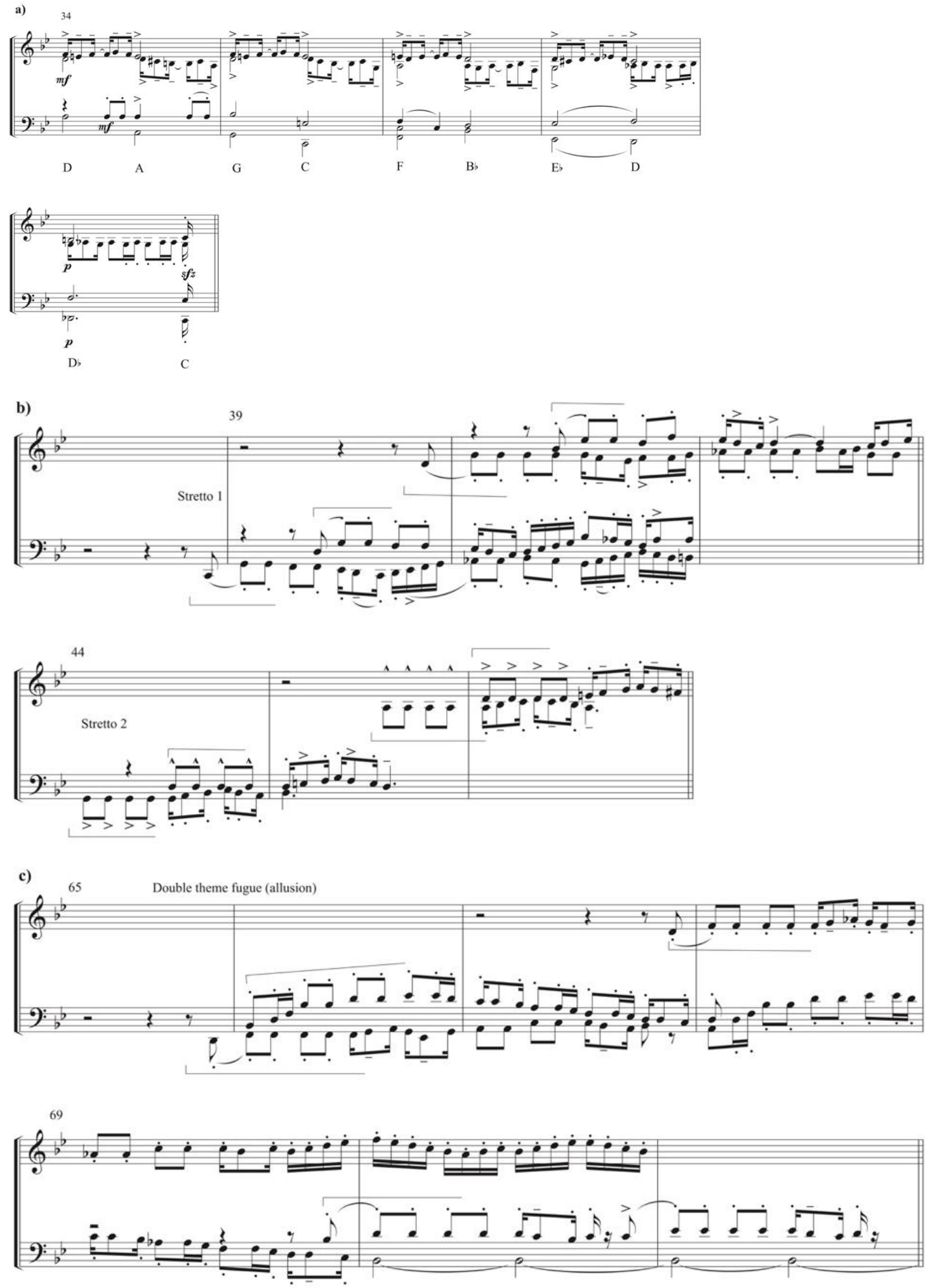

Examples 15a-c: mm. 34-38; 38-46; 65-71; third movement

\section{MUSICA THEORICA}

Revista da Associação Brasileira de Teoria e Análise Musical Journal of the Brazilian Society for Music Theory and Analysis @ TeMA 2017 - ISSN 2525-5541 
Finally, the last section, Episode 4, and after a B flat (tonic) pedal point in $\mathrm{mm}$. 70-73, the section presents the subject in augmentation in $\mathrm{mm}$. 74-81, as shown in Example 16. Once more, the composer alludes to another technique that demonstrates his knowledge of contrapuntal technique, and, naturally, engenders intertextual allusions to learned style.

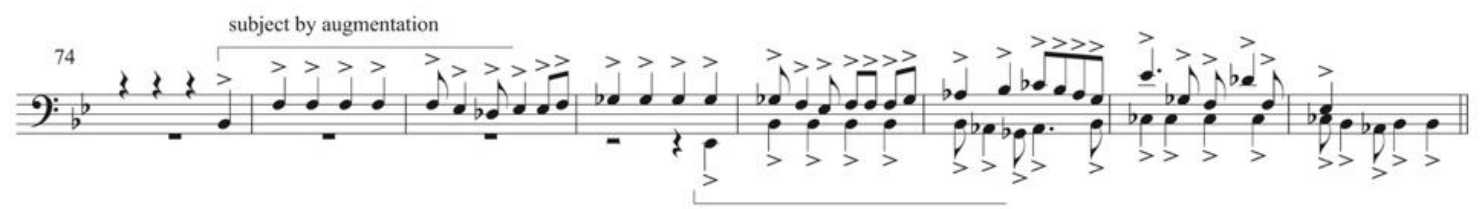

Example 16: mm. 74-81; third movement

\subsubsection{Topics: Polyphonic melody ${ }^{14}$}

Examples of polyphonic melody are also a frequent topic in the Bachianas cycle and could be associated with a stylization element by Villa-Lobos. Example $17 \mathrm{a}-\mathrm{c}$ illustrates three themes in the first movement of the work. The first and the third themes are related since they present segments of compound melodies, as indicated by the prolonged beams. The first begins with an ascending arpeggio that projects the $\mathrm{C}$ minor triad and an alternating descending line in which the lower line delineates $\hat{5}-\hat{4}-\hat{3}-\hat{2}-\hat{1}$ into the cadence in $\mathrm{mm}$. 20-21. The second theme is presented in E flat major in which the first segment of the compound melody leads to $\hat{5}$, and the second segment delineates the $\hat{5}-\hat{4}-\hat{3}-$ $\hat{2}-\hat{1}$ descending line. Example $17 \mathrm{~b}$ illustrates a secondary theme in E flat major that presents a motivic relation to the first theme; the ascending arpeggio of $\mathrm{E}$ flat major triad associates both themes (motives $a$ and $a^{1}$ ). The manner in which VillaLobos derives and relates different themes in the work, using motivic segments in order to link different musical ideas also suggests a search for organicism.

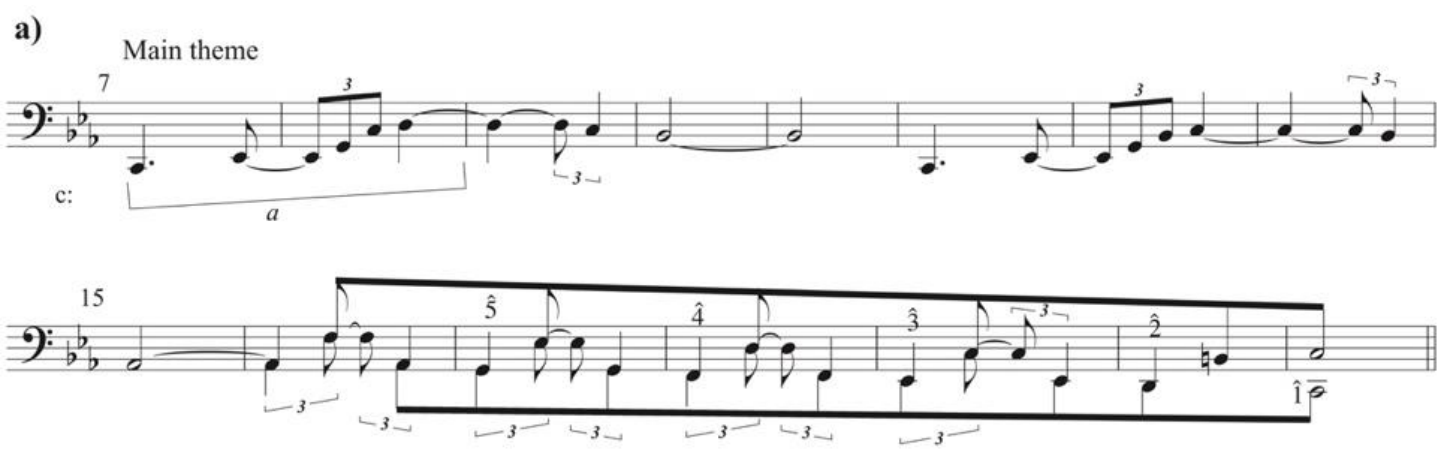

${ }^{14}$ Or compound melody. Cadwallader and Gagné (1998) define as "a melody that articulates two or more distinct voices" (p. 23-4) and also Allen Forte and Steven E Gilbert (1982), p. 67-82. 
b)

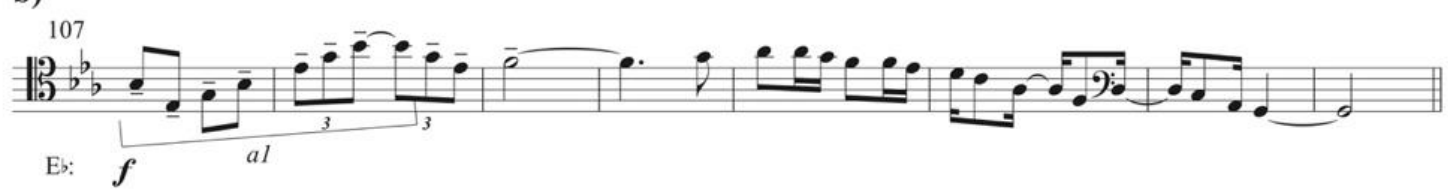

c)

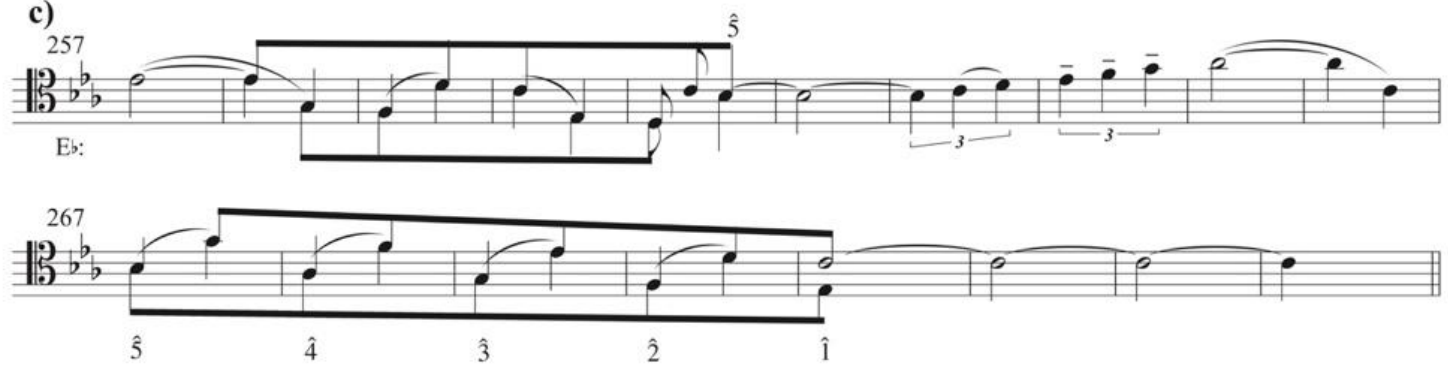

Example 17a-c: Polyphonic melodies, first movement

In sum, the preceding examples illustrate how Villa-Lobos alludes to, adapts, and utilizes, traditional tonality and counterpoint techniques in order to create a Bachian stylization. The use of specific topics of learned style suggest the Villa-Lobos replicates frequent compositional procedures found in the music of the past. Finally, the next section in this text approaches Villa-Lobos's "other stylization", the one that refers to Brazilian popular/folkloric music.

\subsubsection{Typical Brazilian mood}

Several of the movements within the cycle of Bachianas Brasileiras present a double designation alluding to both Bachian and to Brazilian musical genres. For instance, in Bachianas № 1, the first movement is entitled as Introduction (Embolada), the second as Preludio (Modinha), and the third Fugue (Conversa). This sort of Brazilian suite had already been suggested in Mario de Andrade's Ensaio Sôbre a Música Brasileira of 1928. He defends that "Brazilian Suites" should be named after Brazilian folkloric dances. His suggestion is organized as:

1 - Ponteio (prelude in any meter and tempo);

2 - Cateretê (fast binary meter);

3 - Coco (slow binary meter), (choral polyphony), (substitute for sarabanda);

4 - Moda ou Modinha (in ternary or quaternary meter), (substitute for Aria Antiga);

5 - Cururú (for using Amerindian [Brazilian] motive), (one could imagine an African dance when using an Afro-Brazilian motive), (no predetermined tempo);

6 - Dobrado (or Samba, or Maxixe), (fast binary tempo and pompous finale) (p. 68-69).

Andrade's guidelines for Brazilian Suites emphasizes the nationalistic tendency in Brazilian music of the time. He was emphatic that Brazilian music 
should use popular and folkloric music as a source of inspiration. As Wisnik (1982) observes, Andrade's ideological leadership defined that the systematic use of folkloric music was a sine qua non condition for composers to be considered as part of the "Brazilian musical republic" (p. 142), otherwise they would be expelled, as should a "stone in the boot"15.

The first of the three movements of Bachianas № 1, is subtitled Embolada. According to Mario de Andrade's Dicionário da Música Brasileira (1989), embolada is defined as a process that consists of a fast tempo with many repeated notes, and constructed as a "perpetuum mobile", in $16^{\text {th }}$ notes in a $2 / 4$ binary meter ( $p$. 199-200). Almeida (1942) describes in more details. He writes that

One of the most well-known types of côco is the côco of embolada. It is a rhythmicmelodic process of forming a strophein specific northeast choreographic pieces or not. When an embolada appears in a côco dance, the piece takes on the name of côco, when it is not danced (choreographed), even though it always has a refrain, it is called embolada [...] the effect of emboladas result from a very fast tempo, embroiled, demanding from the singer an outstanding diction in order to understand thelyrics, in a hastened rhythm, with the refrain ending in á (p. 167).

Almeida illustrates an Embolada in his book, História da Música Brasileira, as shown in Example 18a, and in Example 18b there are excerpts from Andrade's book Ensaio Sôbre a Música Brasileira illustrating a samba do matuto from the state of Pernambuco and a Côco de Engenho Novo from the state of Rio Grande do Norte. Many of these dances share genre equivalences. For instance, in Example 18b, the lyrics for the Samba do Matuto, allude to the virtuosic traçado that is a synonym for embolada ${ }^{16}$. Furthermore, the characteristic repeated notes, fast tempo and diction virtuosity can be found in another genre, the Desafio (Challenge). Example 18c shows another excerpt from Ensaio, that illustrates a Desafio. The similar characteristics of these songs suggest that Villa-Lobos intended more towards a sort of stylization of the genre of embolada, than to a precise reproduction of folkloric song.
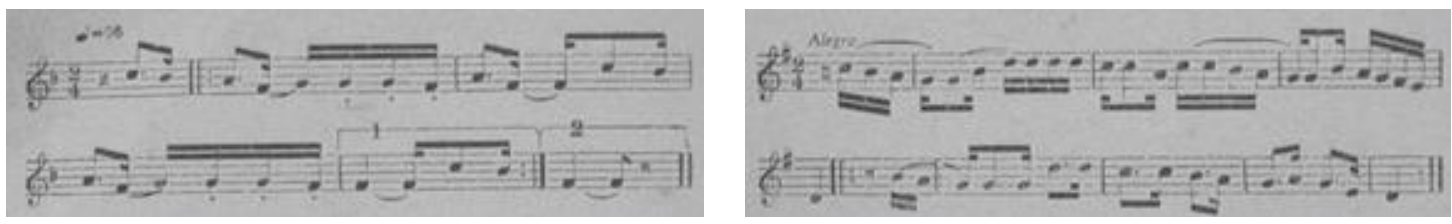

Example 18a: Côco, Almeida História, 168

\footnotetext{
${ }^{15}$ See also Andrade (1928), p. 18.

${ }_{16}$ Andrade quotes the lyrics for the Samba do Matuto: "Eu ando atrai dum poeta de Alagoa/Pela rima e o traçado que ele fai!" [I search for a poet from Alagoa/for the rhyme and the embolada (traçado) [verbal virtuosity] that he does! Andrade also annotates that Traçado = Trocadilho, embolada, verbalismo de complicação proposital [Traçado = a pun, embolada, proposital, complicated verbalism] (Andrade (1928), p. 103).
} 

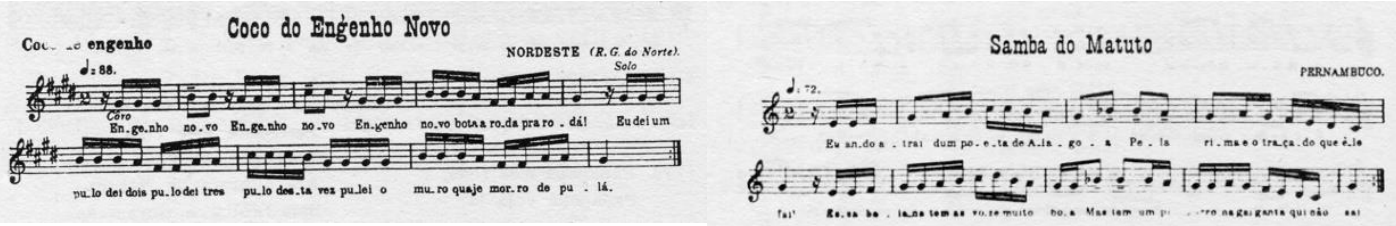

Example 18b: Samba do Matuto e Coco do Engenho Novo, Andrade Ensaio 1972, p. 102, 114

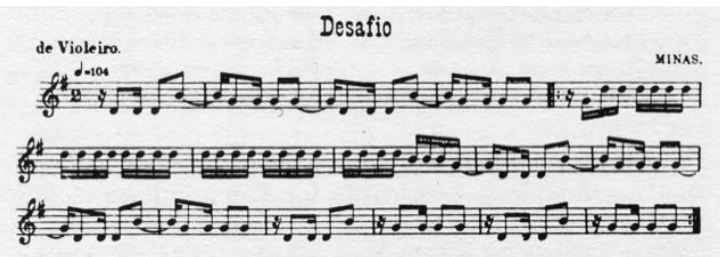

Example 18c: Desafio, Andrade Ensaio, 1972, p. 139

Villa-Lobos's Embolada theme stylizes the characteristics described by Andrade and Almeida: repeated notes, fast rhythm, and an additional feature the improvisational gesture, which is also characteristic of the popular singing in côcos, emboladas and desafios. In Villa-Lobos's theme, shown in Example 19, not only the fast tempo, repeated notes, syncopated rhythm, etc. are alluded in its design, but also the improvisational figures represented by the succeeding triplets, quintuplets and $16^{\text {th }}$ notes.

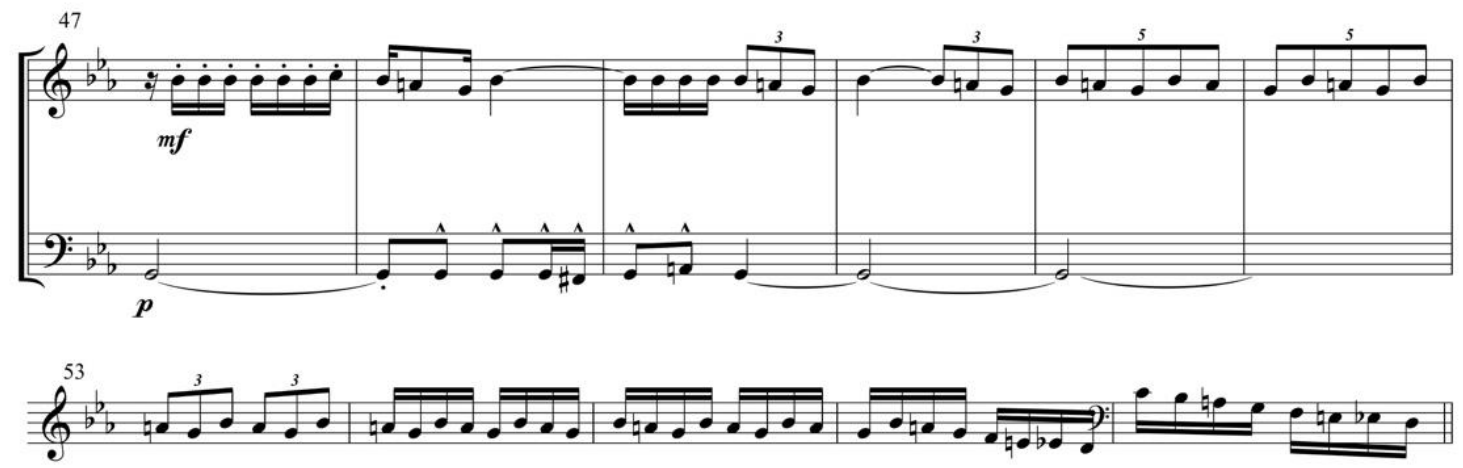

Example 19: Embolada theme - mm. 47-57, first movement

In the second movement, Villa-Lobos refers to the character of an aria, despite the designation of the movement as Preludio, and modinha, a type of melodic song of the Brazilian imperial period. However, it is in the third movement that once again Villa-Lobos alludes to popular music, this time the choro. He argues that the work is composed in the manner of Sátiro Bilhar, one of his choro circle companions, and the fugue characterizes a type of conversation between players. The subject in the fugue, Example 20, illustrates the sort of 
stylization adopted by Villa-Lobos. The melody is constructed with a clear tonality and presents repeated staccato notes and syncopated rhythms. The moderate tempo (un poco animato) alludes to a choro tempo (a comfortable tempo).

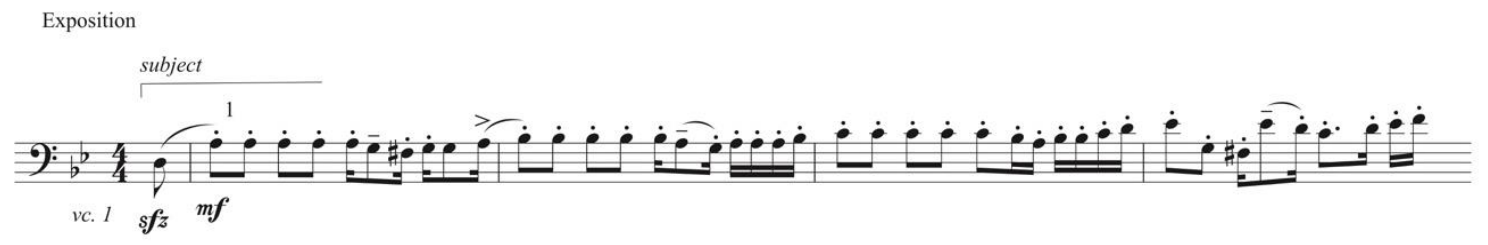

Example 20: Fugue subject, mm. 1-4, third movement of Bachianas № 1

\section{4 - Final remarks}

The term stylization, as understood in Sant'Anna's intertextuality theory, involves the use of stylistic elements from other works, styles and authorial [compositional] languages, resulting in two poles of intertextuality: parody or paraphrases, both mediated by stylization. The case of Bachianas Brasileiras № 1 may be seen as a type of paraphrases with the use of stylistic elements related to neoclassical music. In other words, it is a "different" type of neoclassicism in which the composer invokes the atmosphere of Baroque music, from J. S. Bach's music in particular, and of Brazilian music, especially that from folkloric music and, to a certain extent, from choro music as well. Tonality is an important element since it links the work to tonal common-practice; traditional form is also alluded, in particular in the Preludio (Modinha) and Fugue (Conversa) pair. In fact, the Preludio presents compositional procedures such as theme augmentation and a form that resembles to an A-B-A form. In the fugue, there are allusions to fugal procedures such as double fugue, and stretti, however, the most noticeable characteristic is its approximation to the fugue d'école as established by Gedalge and by D'Indy. In these two movements, tonality is decisive; it defines the general formal design of the pieces and their overall atmosphere, consequently, an element of stylization. In addition, Villa-Lobos's stylization may be seen as replicating compositional practices of the past, a case in point, is concerned with learned style.

Brazilian popular music is part of the stylization adopted by Villa-Lobos. In the Introduction (Embolada) the rhythm drive of an embolada is perceived according to the continuous movement, the section that presents references to folkloric embolada also provides an improvisatory atmosphere typical of this type of music. Finally, the theme of the fugue also suggests, with its syncopated rhythm, a choro-like theme, however the predominating atmosphere is the traditional fugue. 
Nevertheless, it is important to observe that Villa-Lobos's stylization of Bach's compositional procedures sets the Bachianas Brasileiras № 1 apart from a mere imitation of Bach's music and of Brazilian popular music. In fact, although the Bachian stylization may be evident in the foreground, however, the music is only indirectly related to Bach's music (and to Brazilian popular music as well). The general aura of the work is that of an homage to J.S. Bach and to Brazilian popular music, without, however, losing the relationship to the composer's stylistic procedures of his own music. In this sense, intertextuality provides a way to contextualize and relate the work to specific compositional techniques contributing to the understanding of the work. As the analysis demonstrates, the work presents a coherent structure that allows it to defend its own organic autonomy, despite the many intertextual references and allusions. Moreover, despite the 1930 date of composition, the Bachianas № 1 already demonstrates a mature conception of compositional style, procedures and techniques, etc. that are the basis for the remaining pieces in the cycle. The hiatus of eight years between the composing of Bachianas № 1 and 2, and the composition of № 3 in 1938, Villa-Lobos had arranged works by J. S. Bach for mixed choir and celli orchestra that may have served him as a period of further study of Bach's music, improving his already comprehensive conception of the Bachianas style.

Finally, paraphrasing Hyde, the Bachianas Brasileiras № 1 is a reverentialeclectic imitation of earlier music. In it, one can find allusions, echoes, phrases, techniques, structural elements and forms from a group of earlier music that ranges from Bach to Brazilian music, all mixed indifferently in a "Villa-Lobian neoclassical style".

\section{Acknowledgements}

This research was partially supported by a CNPq "PQ2 Productivity Fellowship"

\section{References}

1. Agawu, Kofi. 2009. Music as Discourse Semiotic Adventures in Romantic Music. Oxford: Oxford University Press.

2. Andrade, Mário de. 1928. Ensaio Sôbre a Música Brasileira. São Paulo: Livraria Martins Editora.

3. Andrade, Mario de. 1989. Dicionário Musical Brasileiro. Edited by Toni, Flavia Camargo and Alvarenga, Oneyda. São Paulo: Ministério da Cultura e Instituto de Estudos Brasileiros da Universidade de São Paulo. 
4. Almeida, Renato. 1942. História da Música Brasileira. Rio de Janeiro: F. Briquiet.

5. Béhague, Gerard. 1994. Heitor Villa-Lobos: The Search for Brazil's Musical Soul. Austin: Institute of Latin American Studies University of Texas at Austin.

6. Bach, Johann Sebastian, and Heitor Villa-Lobos. 1991. Préludes et Fugues d'aprés Jean-Sébastien Bach: Pour Orchestre de Violoncelles. Paris: Editions Max Eschig.

7. Bloom, Harold. 1997. The Anxiety of Infuence: A Theory of Poetry. Oxford: Oxford University Press.

8. Cadwallader, Allen and Gagné, David. 1998. Analysis of Tonal Music: A Schenkerian Approach. Oxford: Oxford University Press.

9. Chapin, Keith. 2014. "Learned Style and Learned Styles." In: The Oxford Handbook of Topic Theory, edited by Danuta Mirka, p. 301-329. Oxford: Oxford University Press.

10. Corrêa do Lago, Manuel Aranha. 2010. O Círculo Veloso-Guerra e Darius Milhaud no Brasil. Rio de Janeiro: Reler.

11. Dickensheets, Janice. 2012. The Topical Vocabulary of the Nineteenth Century. Journal of Musicological Research 31 (2-3), p. 97-137.

12. D’Indy, Vincent. 1903. Cours de Composition Musicale. Paris: A. Durand et Fils.

13. Finscher, Ludwig. 1998. Bach's Posthumous Role in Music History. Bach Perspectives 3, p. 1-21.

14. Forte, Allen and Gilbert, Steven. 1982. Introduction to Schenkerian Analysis. New York and London: Norton.

15. Gedalge, André. 1901. Traité de La Fugue. Paris: Enoch \& Cie.

16. Hatten, Robert S. 2014. The Troping of Topics in Mozart's Instrumental Works. In The Oxford Handbook of Topic Theory, edited by Danuta Mirka, p. 514536. Oxford: Oxford University Press.

17. Horton, Julian. 2014. Listening to Topics in the Nineteenth Century. In: The Oxford Handbook of Topic Theory, edited by Danuta Mirka, p. 642-664. Oxford: Oxford University Press. 
18. Hyde, Martha M. 1996. Neoclassic and Anachronistic Impulses in TwentiethCentury Music. Music Theory Spectrum 18 (2), p. 200-235.

19. Korsyn, Kevin. 1991. Towards a New Poetics of Musical Influence. Music Analysis 10 (1), p. 3-72.

20. Klein, Michael. 2005. Intertextuality in Western Art Music. Bloomington: Indiana University Press.

21. Messing, Scott. 1988. Neoclassicism in Music from the Genesis of the Concept through the Schoenberg/Stravinsky Polemic. Rochester: University of Rochester Press.

22. Milhaud, Darius. 1920. Brésil. La Revue Musicale 1, p. 60-61.

23. Museu Villa-Lobos. 1972. Villa-Lobos, Sua Obra. Rio de Janeiro: MEC/Museu Villa-Lobos.

24. Nóbrega, Adhemar. 1969. Roteiros de Villa-Lobos. In: Presença de Villa-Lobos, p. 7-26. Rio de Janeiro: MEC/DAC/Museu Villa-Lobos.

25. Nogueira, Ilza. 2003. A Estética Intertextual na Música Contemporânea: Considerações Estilísticas. Brasiliana 13, p. 2-12.

26. Ratner, Leonard. 1980. Classic Music - Expression, Form, and Style. New York: Schirmer Books.

27. Sant'Anna, Afonso Romano de. 2003. Paródia, Paráfrase \& Cia. São Paulo: Ática.

28. Squeff, Enio and Wisnik, José Miguel. 1982. O Nacional e o Popular na Música Brasileira. São Paulo: Brasiliense.

29. Straus, Joseph N. 1990. Remaking the Past: Musical Modernism and the Influence of Tonal Tradition. Cambridge: Harvard University Press.

30. Tarasti, Eero. 1995. Heitor Villa-Lobos: The Life and Works, 1887-1959. London : McFarland. 
31. Toorn, Pieter C. van den. 1997. Neoclassicism and Its Definitions. In: Music Theory in Concept and Practice, edited by James M Baker, David W. Beach, and Jonathan W Bernard, p. 131-156. Rochester: University of Rochester Press.

32. Villa-Lobos, Heitor. 1946. Solfejos Originais e sôbre Têmas de Cantigas Populares, para Ensino de Canto Orfeônico. Rio de Janeiro: Irmãos Vitale.

33. Walker, Paul. 2001. Fugue, §8 20th Century. In: The New Grove Dictionary of Music and Musicians, 2nd ed., Stanley Sadie and John Tyrrell (Editors), Vol. 9, p. 330-331. London: Macmillan.

34. Wright, Simon. 1992. Villa-Lobos. Oxford: Oxford University Press. 